\title{
História, experiência e modernidade na América ibérica, 1750-1850
}

History, Experience and Modernity

in Portuguese and Spanish America, 1750-1850

\section{Guillermo Zermeño Padilla \\ Centro de Estudios Históricos, El Colegio de México}

\begin{abstract}
Resumo
Baseado na proposta de Reinhart Koselleck são examinados nove casos distintos na América ibérica para averiguar se nessa região houve a experiência da história conhecida como "moderna". Esta nova experiência se caracterizaria por desarticular e reconfigurar as relações clássicas de temporalidade. A partir dos resultados obtidos nossa hipótese teve uma resposta afirmativa, ainda que possamos observar justaposições e não necessariamente um desenvolvimento uniforme. Isto se verifica especialmente na comparação das experiências históricas de antigos centros imperiais (Madri e Lisboa) com aquelas das antigas colônias (Argentina, Brasil, Chile, Colômbia, Peru, México, Venezuela).
\end{abstract}

\begin{abstract}
Based on the proposal of Reinhart Koselleck, this paper examines nine different cases of Portuguese and Spanish America in order to check whether those regions went through the "modern" historical experience. This new experience could be distinguished by the disarticulation and the reconfiguration of the classical relations of temporality. According to research results, I argue that the answer in affirmative, even if we observe overlapping and a not necessarily uniform development. Especially, this is noticeable when we compare the historical experiences of the old imperial centers (Madrid and Lisbon) and the former colonies (Argentina, Brazil, Chile, Colombia, Peru, Mexico, Venezuela).
\end{abstract}

\section{Palavras-chave}

história das idéias, modernidade, Independência, nação, historiografia, América

\section{Keywords}

history of ideas, modernity, Independence, nation, historiography, America
Estendo meu agradecimento particularmente a Sergio Campos Matos, Javier Fernández Sebastián, Valdei Lopes de Araújo, João Paulo Pimenta, Peer Schmidt e Victor Samuel Rivera, que me permitiram melhorar versões prévias com seus comentários e sugestões críticas. 
Os resultados destes estudos serão publicados em breve no Diccionario Politico y Social Iberoamericano. Conceptos políticos en la era de las independencias, 1750-1850, Madrid, Centro de Estudios Políticos y Constitucionales.

N.T.: em português, estão disponiveis Critica e crise: para uma patogênesis do mundo burguês. Rio de Janeiro: Contraponto/Eduerj, 1999 e Futuro Passado. Rio de Janeiro: Contraponto, 2006.

4

Por exemplo, um historiador mexicano, por volta de 1950, escreve: "Acreditamos que na Reforma está a chave da Modernidade; na qual - digamos de passagem - ainda nos encontramos os povos hispânicos, não por casualidade nem por falta de luzes, mas um pouco como a contragosto ou como hóspedes às vezes estranhos e, em muitas outras, morosos. Não será ocioso então, acrescentar que na Reforma está a chave da Antimodernidade hispânica". ORTEGA Y MEDINA, Juan. Reforma y modernidad. México: Alicia Mayer González ed., 1999. p 23. Para uma análise dos paradoxos inscritos na "modernidade moderna" ver, LUHMANN, Niklas. Lo moderno de la sociedad moderna: complejidad y modernidad, de la unidad a la diferencia. Madrid: Trotta, 1998. p.131-153.

\section{5}

SEBASTIÁN, Javier Fernández. "Modernidad". IN SEBASTIÁN, Javier Fernández y FUENTES, Juan Francisco (orgs.). Diccionario político y social del siglo XIX español. Madrid: Alianza Editorial, 2002. p.453-462. KOSELLECK, Reinhart.

Vergangene Zukunft. Zur Semantik geschichtlicher Zeiten. Frankfurt: 1979. p.302; Versão em espanhol: Futuro Pasado. Para una semántica de los tiempos históricos. Barcelona: 1993. p.289. 0 termo "modernidade" (Modernität) sintetiza qualquer evento relacionado com o recente, o atual, o moderno. 0 surgimento do conceito mostra a condensação de uma experiência complexa, multifatorial.
Neste ensaio pretende-se realizar uma sintese comparativa da evolução do termo "história" e sua relação com a formação de um novo espaço de experiência caracterizado como "moderno". É um exercício feito desde nosso contexto lingüistico e cultural, situado e enriquecido pelas contribuições do historiador alemão Reinhart Koselleck. A análise baseia-se fundamentalmente nas contribuições feitas sobre nove paises: Fabio Wasserman (Argentina), Valdei Lopes de Araújo/ João Paulo Pimenta (Brasil), Jorge Orlando Melo (Colômbia), Aldo Yávar Meza (Chile), Pedro José Chacón Delgado (Espanha), Guillermo Zermeño (México), Víctor Samuel Rivera (Peru), Sérgio Campos Matos (Portugal) e Ángel Rafael Almarza Villalobos (Venezuela). 2 Sem tirar a responsabilidade própria de quem escreve este texto, considero que, essencialmente, trata-se de um ensaio coletivo. As contribuições mencionadas nos permitem olhar para além de nossas fronteiras culturais, o que não é pouco.

Sendo assim, primeiramente me permitirei apresentar uma sintese da proposta ou hipótese geral desenvolvida por Koselleck. Seus textos são de domínio público, e a maioria deles está à disposição em castelhano há alguns anos. ${ }^{3}$ Assim, minha aproximação tem apenas a função de estabelecer os limites dentro dos quais se procurará elucidar a entrada do mundo ibero-americano na modernidade. Trata-se de um contexto cultural cheio de equivocos, em geral ainda rodeado por uma espécie de "lenda negra" que, paradoxalmente, continua vigente ao mesmo tempo em que vão criando-se as condições para a formação de um novo tipo de experiência histórica ou de temporalidade descrita como "moderna".

Estabelecida a moldura conceitual característica dos conceitos "modernos" de história e modernidade, é possivel pensar e definir os limites em que é legítimo abrir o compasso para a comparabilidade entre diversos tipos de experiências da história mantidas em linguagens e culturas limítrofes. Como foi dito anteriormente, no contexto alemão, o trabalho de elucidação foi realizado, entre outros, por Koselleck, labor que é possivel iniciar em nosso contexto, contando com a colaboração daqueles que fazem parte ativa deste projeto. Por isso, mais que indicar o ponto de chegada, estas linhas têm o objetivo principal de iniciar um trajeto de investigação; trata-se somente de indicar um ponto de partida para continuar avançando neste tipo de pesquisa, especialmente, sobre o conceito de história.

\section{PREÂMBULO METODOLÓGICO}

\section{A modernidade como conceito histórico}

Como anunciado no título, ao longo do texto dá-se especial ênfase a três conceitos limitrofes: história, experiência e modernidade. A menção desta última noção contém particularmente uma carga polêmica, exigindo, portanto, desde o início, seu esclarecimento.4 "Modernidade" é um termo atualmente em voga, de uso comum que serve basicamente para referirse ao que é mais atual, ao mais novo. Seu uso mais ou menos constante mostra que se trata de um termo empregado para descrever a dinâmica das sociedades contemporâneas. Mas seu aparecimento como substantivo genérico é relativamente recente, segundo o Diccionario político y social del siglo XIX español. Em língua castelhana, talvez seja o filósofo José Ortega y Gasset quem o consagra, a partir da década de 1910. Já em língua alemã seu surgimento se registra a partir de $1870 .^{5}$

Diante de uma noção de "modernidade" fundada em uma história das idéias e cuja origem remete às guerras de religião do século XVI, aqui se contrapõe uma noção de modernidade fundada em uma história dos 
Na perspectiva da sociologia de sistemas, Niklas Luhmann é um dos autores que, com maior radicalismo, apresenta os problemas não só históricos, mas principalmente lógicos, para descrever o que acontece no interior desta "modernidade moderna" e suas conseqüências. Ver a esse respeito LUHMANN, Niklas. Lo moderno de la sociedad moderna: complejidad y modernidad, de la unidad a la diferencia. Madrid: Trotta, 1998. p.131-153.

Em relação a este tema, é de interesse o livro de LOMNITZ, Claudio. Modernidad Indiana. Nueve ensayos sobre nación y mediación en México. México, 1999. p.9-12. Ainda que em um primeiro momento recupera a dimensão qualitativa da noção de modernidade (Weber e Habermas), não consegue desprender-se do esquema que situa sua origem no século XVI, com a conseqüência de que o México aparece às vezes como moderno e outras vezes antimoderno. Nesta versão parece dominar ainda uma concepção instrumental da modernidade intimamente ligada à "modernização". No fim, o termo modernidade aparece como uma noção ideológica, e não tanto como uma experiência de temporalidade.

8

KOSELLECK, Reinhart. Vergangene Zukunft. Zur Semantik geschichtlicher Zeiten. Frankfurt: 1979. p.310, (Versión española, p.296-7). Também, GRUMBRECHT, Hans Ulrich. A History of the Concept "Modern": Making Sense in Life and Literature. Minneapolis: 1992. p.79-110; OSBORNE, Peter. Modernity is a Qualitative, Not a Chronological Category. New Left Review London, 192, p.65-84.

Em uma historiografia cumulativa dominada pela cronologia, a periodização não remete às novidades do tempo em que se encontram os historiadores, mas sim aos novos dados proporcionados pelo passado.

10

KOSELLECK, Reinhart. Op. Cit. p.311; (Versão espanhola p.297-298).

11

Ibidem, p.315 (Versão espanhola p.301) conceitos. De acordo com o primeiro enfoque, prevalece uma linha de continuidade entre as experiências do século XVI e as do XX. Ao contrário, a Begriffsgechichte permite mostrar precisamente as descontinuidades por meio da análise da linguagem ou dos atos de fala. A partir desta perspectiva, seria impróprio falar de origens da modernidade no século XVI, por não ser encontrado, no vocabulário da época, o uso da palavra "modernidade" tal como será desenvolvido a partir do século XIX. Uma noção "moderna" do moderno, alimentada e seguida retrospectivamente por historiadores, filósofos ou antropólogos "modernos". Desde a situação da historiografia atual, trata-se de uma elaboração intelectual que não permite distinguir os traços próprios da cultura que domina e marca os que habitaram o mundo a partir do século XVI. ${ }^{6}$ É a partir dessa modernidade plenamente implantada na linguagem do século XX que Ortega y Medina (citação 2) realizou seu exercício retrospectivo para tentar descrever as anomalias do processo ibero-americano em relação ao das culturas do norte da Europa.

Aqui se defenderia que as origens da modernidade remontam ao periodo que vai do final do século XVIII ao século XIX, e que os indícios desta mutação semântica situam-se no vocabulário de seus contemporâneos. A hipótese seria a seguinte:

a) A noção de modernidade se relaciona estreitamente com a de experiência, já que se trata de uma categoria histórico-qualitativa e não meramente cronológica. ${ }^{7}$ Esta característica distintiva consiste em que o termo já não designa somente o novo, mas que se apresenta como uma experiência inédita, sem semelhanças com outras anteriores. Por esse motivo, o passado começa a deixar de ter funções normativas no presente. Assim, o surgimento de um tempo especificamente moderno supõe a criação de um novo espaço de experiência, fundado menos na emulação do passado e muito mais em futuros projetados. Esta discordância entre o passado conhecido e o futuro desejado gera um discurso histórico que paradoxalmente o distancia progressivamente das épocas pretéritas. ${ }^{8}$

b) 0 traço distintivo desta modernidade é, então, sua relação com a temporalidade. Na vida cotidiana o tempo flui como um continuum para todos. 0 amanhã é transformado pelo hoje em um ontem. $\mathrm{Na}$ historiografia pré-moderna, por exemplo, registram-se e fixam-se os acontecimentos por escrito, cronológica e cumulativamente. 0 presente existe apenas como limite dos acontecimentos narrados. De acordo com presentes ulteriores, irão se adicionando e completando as relações. Sem entrar na análise da retórica dos textos, estes relatos históricos transmitem a impressão de um presente contínuo enriquecido com os fatos do passado, que se amplia e se estende de forma progressiva. ${ }^{9}$ Também mostram a formação de um espaço de experiência mais ou menos homogêneo e constante. Por essa razão, ao mais recente não se outorga um peso específico - ou porque as histórias se repetem em sua estrutura ou porque antes do fim do mundo não é de se esperar que ocorra algo completamente diferente.10 Para que isto ocorra, seguindo Koselleck, é preciso que a expectativa cristã do juízo final perca "seu caráter de presente continuo".11 E esta reflexão, inclusive, não é desenvolvida inteiramente durante o chamado século da Ilustração. No estudo de Koselleck, ela começa a formar-se somente depois de 1789. Um sentido do tempo como aceleração, independente do esquema escatológico cristão, começa a ganhar relevância apenas 
12

KOSELLECK, Reinhart. Vergangene Zukunft. Zur Semantik geschichtlicher Zeiten. Frankfurt: 1979. p.318-21; (versão espanhola p.305-7). Koselleck utiliza a expressão neueste Geschichte e não gegenwärtige Geschichte, que pressupõe a neue Geschichte ou "história mais recente", sinônimo de moderna. De modo que, além da noção moderna que diferencia essa época da antiga e da medieval, se introduz mais outra: a "mais nova" ou mais recente, que Ranke situa a partir da revolução americana e francesa. 0 sufixo -ste mostra que se deixa atrás o comparativo -ere, para designar que se trata de uma história acabada, própria, diferente, que não se assemelha a outra. A diferença entre o neue Zeit e o neueste Zeit marcaria então o momento em que a "modernidade" começa a sustentar-se sobre si mesma.

13

Ibidem, p.317-8; (versão espanhola p.303-4). Uma expressão historiográfica desta "modernidade" própria da segunda metade do sécuIo XVIII é o trabalho de RANKE, Leopold Von. Pueblos y Estados en la historia moderna. (tr. Wenceslao Roces). México, FCE, 1979. (1a ed. em espanhol de 1948). Trata-se de uma compilação de trabalhos de Ranke publicados na Alemanha em 1945, de modo que o título provavelmente não é autoria do próprio Ranke. Somente o capitulo dedicado a "Epocas en la Historia" foi retirado de uma obra editada em 1888 , um período em que o conceito de modernidade já estava disseminado, com o título "Sobre las épocas de la historia más reciente o moderna" (Über die Epochen der neueren Geschichte). É o esquema proposto por obras como as de Ranke que inspira o trabalho mencionado acima, de Ortega y Medina, para pensar a complexa entrada dos paises ibero-americanos na modernidade.

14

SEBASTIÁN, Javier Fernández. "Modernidad". IN: SEBASTIÁN, Javier Fernández y FUENTES, Juan Francisco (orgs.). Diccionario politico y social del siglo XIX español. Madrid: Alianza Editorial, 2002. p.453-462.

15

A explicação disso reside no fato de que toda época é cega no momento de observar. A época experimenta a vivência da aceleração do tempo, mas não consegue ver a aceleração em si.

\section{6}

Kant já havia observado que a cronologia devia ser estabelecida de acordo com a história, e não esta segundo o desenvolvimento da cronologia. Este giro pressupõe a separação de uma cronologia vinculada ao ciclo da natureza e ao da sucessão das dinastias reinantes. Preparado por Vico, acrescenta Koselleck, estava nascendo um tempo especificamente "histórico". KOSELLECK, Reinhart. Futuro Pasado. Para una semántica de los tiempos históricos. Barcelona: 1993. p.308 a partir da primeira década de 1800, associado à ressemantização de antigas palavras como "revolução", "progresso", "desenvolvimento", "crise", "espírito do tempo", todas elas traduzindo a nova experiência do tempo em termos de movimento. ${ }^{12}$

Nota-se também que a modernidade - como noção não-cronológica e sim qualitativa ou de experiência alimentada pelas expectativas de futuro - não é constitutiva ainda da discussão historiográfica do século XVIII. Mas o é, por outro lado, a integração de um conceito de modernidade que permite diferenciar a própria época de outra, como a Idade Media, cuja duração não vai além de três séculos. ${ }^{13} \mathrm{~A}$ parte final deste processo é o surgimento da noção de história contemporânea no interior da história moderna por volta de 1775 , indicando assim uma mudança na percepção do tempo como aceleração.

c) Da mesma forma, se pode ver a evolução do conceito "moderno" ligado ao de "história". Sua trajetória vai das Historien, ou crônicas tradicionais associadas a um espaço de experiência que permanece fundamentalmente idêntico a si mesmo; passa em seguida ao de "história" entendida como processo autônomo, até desembocar em um tempo caracterizado como moderno sem mais, que depende cada vez menos do passado e mais do futuro.

d) Trata-se de uma experiência global que atravessa tanto paises metropolitanos como as províncias imperiais. A ressemantização do vocábulo "história", ao lado de outros conceitos vizinhos como "progresso" e "cultura", seria um dos indícios da criação de um novo espaço de experiência que imprime sua marca a esta época. ${ }^{14}$

e) Derivado do que foi exposto anteriormente, a forma como se concebia a modernidade até a década de 1950 apenas continua um esquema de periodização fabricado durante a segunda metade do século XVIII, no qual se enfatiza o caráter cronológico, deixando de lado o caráter qualitativo relacionado com a noção de experiência temporal. ${ }^{15} \mathrm{Sem}$ este aspecto, na hipótese crítica que nos propõe Koselleck, a modernidade não chega a compreender o que implica ser parte da modernidade. Mas, como se sugeriu, uma nova caracterização da modernidade só é possivel se agregamos à cronologia um caráter qualitativo. ${ }^{16}$ Assim, esta não se deve tanto a fenômenos puramente externos, mas sim à forma como eles vão sendo processados. Nesse sentido, mais que à história econômica, a compreensão da modernidade como experiência temporal pertence ao espaço da história intelectual e cultural. Está relacionada com o processo de interiorização de um novo tipo de experiência não redutivel a indivíduos isolados, mas à sociedade em conjunto. Uma das características desta modernidade - diferente da modernidade humanista ou renascentista - consiste, precisamente, em sincronizar coisas que até então pareciam não ter nenhuma relação. Nisso está a força do novo vocabulário social e político próprio desta modernidade: sua conversão em conceitos singulares e ao mesmo tempo universais.

\section{Linguagem e história}

Uma premissa metodológica central da Begriffsgeschichte é postulada por Koselleck no início de um de seus ensaios. Sintetiza seu programa em uma frase tomada de Friedrich Schlegel quando este refletia sobre o que era, 
17

KOSELLECK, Reinhart. Vergangene Zukunft. Zur Semantik geschichtlicher Zeiten. Frankfurt: 1979. p.349; Versión en español: Futuro Pasado. Para una semántica de los tiempos históricos. Barcelona: 1993. p.333.

18

KOSELLECK, Reinhart; GADAMER, Hans-Georg. Historia y Hermenéutica. Barcelona: 1997. p.117.

19

Ibidem, p.118.

20

François Hartog dá um passo adiante ao propor a noção "regime de historicidade" como ferramenta heuristica "que contribua para apreender melhor não o tempo nem todos os tempos, nem o todo do tempo e sim, principalmente, momentos de crises do tempo, aqui e lá, exatamente quando as articulações entre o passado, 0 presente e o futuro deixam de parecer óbvias"; HARTOG, François. Órdenes del tiempo, regimenes de historicidad. Historia y Grafia, México, 21, 2003. p.98. Aqui, o relevante é a ênfase dada ao fato de detectar os "momentos de crises do tempo", como o que domina na atualidade. No diagnóstico de Hartog, depois de revisar três regimes de historicidade (heróico, clássico e moderno) se estaria em plena crise do regime moderno de historicidade, foco de atenção de nossas análises. Ver seu livro HARTOG, François. Régimes d'historicité. Présentisme et expériences du temps. Paris: 2003. como se conhecia e como se devia escrever a história: "Não se pode dizer que algo é sem dizer o que é". Isto é, não há mundo sem linguagem. "Ao pensar nos fatos, estes por si próprios se referem a conceitos". E esta não é uma questão indiferente: sem conceitos não há mundo. ${ }^{17}$

Os nexos entre "dizer" e "fazer" ganham especial relevância nesse projeto historiográfico, já que não há mundo sem linguagem, nem linguagem sem mundo. Por exemplo, nas línguas germânicas e indogermânicas, na raiz do termo "mundo" (Welt, World) já está incluído o homem (Wer), explica Gadamer. "Mundo" é mundo humano, do homem. ${ }^{18}$ Por conseguinte, o mundo não é um objeto dado de antemão (essa é a crítica de Kant a todo tipo de metafísica dogmática), e conseqüentemente não pode ser explicado como um todo utilizando as categorias da ciência experimental. Mais exatamente, afirma Gadamer, o mundo existe como horizonte de possibilidades, aberto, ao mesmo tempo em que se tenta delimitá-lo e ganhar orientação. Isto é realizado por meio da linguagem e da comunicação. A posição do homem, intermediária entre ser vivo da espécie animal e humana, o coloca por cima das linhas do instinto natural de sobrevivência. ${ }^{19}$ Mostra-o fundamentalmente como um ser que fala. Gadamer denomina esta esfera de "lingüisticidade", como especifica do ser humano, não redutivel exclusivamente ao mundo dos textos; a qual, de acordo com Aristóteles, estabeleceria a pauta principal para diferenciar a condição do ser humano daquela de outros seres vivos.

Portanto, além das categorias históricas para discernir o caráter e sentido da ação social e política, se requer um tipo de categorias suprahistóricas como a da "lingüisticidade", já que os conceitos próprios do historiador são insuficientes para estabelecer as diferenças com as sociedades animais. Nestas se encontram também as relações de poder resumidas em antagonismos tais como, acima/abaixo, supremacia/submissão, dentro/fora, inclusão/exclusão. Segundo Gadamer, o estudo das sociedades animais (etologia) seria muito útil para ensinar-nos sobre as grandes semelhanças existentes entre o reino animal e o humano; mas ao mesmo tempo para mostrar as diferenças. E estas se realizam não de forma natural, mas sim no âmbito da linguagem.

0 corolário desta premissa é que somente por meio da observação e da análise da linguagem é possivel ter acesso ao espaço de experiência próprio de cada época. Permite observar a maneira como as sociedades processam suas relações com a temporalidade. Portanto, a modernidade entendida como forma particular de experiência só é tematizável a partir da observação da evolução das palavras e sua transformação semântica. Koselleck situa esta transformação do sentido de temporalidade durante 0 período de 1750-1850. 20

Nesse sentido, a Begriffsgeschichte proporciona uma das formas possiveis para entrar na história por meio da evolução e transformação do significado das palavras. Situar esta exploração no cenário da modernidade implica, por conseguinte, tentar observar o momento e o contexto em que se foi gerando um novo vocabulário apropriado para essa experiência, trazendo também um novo posicionamento em relação ao mundo e suas possibilidades. Esse é o cenário geral em que se desenvolve a principal hipótese que orienta esta pesquisa.

Se foi descartada a opção de compreender a modernidade como um processo contínuo que abarca cinco séculos, isso se deve ao fato de que não foi capaz de orientar-nos sobre o sentido de temporalidade que a cons- 
21

KOSELLECK, Reinhart. Vergangene Zukunft. Zur Semantik geschichtlicher Zeiten. Frankfurt: 1979. p.349-375; KOSELLECK, Reinhart. Futuro Pasado. Para una semántica de los tiempos históricos. Barcelona: 1993. p.333-357.

22

Assim, Tocqueville, quando visitou os Estados Unidos, pôde constatar, não que a cultura observada era superior a outras, e sim que esta era "diferente" do observado historicamente. TOCQUEVILLE, Alexis de. La democracia en América. México: 1957. p.643-644.

23

KOSELLECK, Reinhart. Op.Cit, p.338 titui. Sua rejeição não significa que não seja possivel reconhecer elementos técnicos que tenham um papel fundamental na composição desse novo espaço de experiência. Mas mais que como elementos ordenados seqüencialmente em termos causais, a maneira como se agrupam estabelece uma diferença ou separação com o momento em que apareceram. Pelo contrario, se partimos da periodização proposta por Koselleck (1750-1850) para identificar a alteração ou mutação do sentido do tempo ("um novo regime de historicidade", nos termos de Hartog), é necessário mostrar as relações que pode haver entre história e experiência.

\section{História e experiência}

Koselleck concentrou-se em elucidar e esclarecer a transformação semântica da palavra história durante este periodo como indício da formação de um novo espaço de experiência. Em sua indagação não se pode separar a observação do uso da linguagem dos contemporâneos (a linguagem do passado) e o uso de uma linguagem própria do historiador (a linguagem do presente). Pois é evidente que a palavra história e suas variantes se encontram nos textos do passado, mas não noções tais como "espaço de experiência" e "horizonte de expectativas". ${ }^{21}$ Estas categorias postuladas a priori - antes de toda experiência - são as que permitiriam estabelecer os nexos possiveis entre linguagem e experiência, e ao mesmo tempo, são as que abrem a possibilidade de comparação entre diversos tipos de experiências históricas.

Na hipótese de Koselleck existe uma relação estreita entre o aparecimento do neologismo Geschichte (história como acontecer) - que paulatinamente vai se impondo ao conceito tradicional Historie (história como relato) - e a formação de um novo espaço de experiência com seu respectivo "horizonte de expectativa". Ambas expressões derivam das categorias kantianas do conhecer (espaço e tempo). E a questão metodológica central consistiria em aprender a distinguir as diversas formas de coordenação que podem ocorrer entre experiência e expectativa, entre passado e futuro. Com este procedimento heurístico compartilhado, o mais provável é que se constataria a diversidade de experiências que podem ocorrer dentro do mesmo. ${ }^{22} \mathrm{~A}$ condição inicial deste tipo de observação consiste em reconhecer a dimensão temporal de toda existência humana. Assim, para Koselleck a experiência "é um passado presente (gegenwärtige Vergangenheit), cujos acontecimentos foram incorporados (einverleibt) e podem ser recordados (erinnert). Na experiência se fundem tanto a elaboração racional como os modos inconscientes do comportamento que não devem - ou já não deveriam - estar presentes no saber". ${ }^{23}$

É evidente que no momento em que a Europa chegou à América encontrou-se com outra cultura, percebeu que esse mundo não era como a Europa. Esta percepção é vigente no século XVIII e inclusive se aprofunda quando o arcebispo do México, Francisco Lorenzana, em 1770, declara que "Dois Mundos pôs Deus (Providência) nas Mãos de Nosso Católico Monarca, e o Novo não se parece ao Velho, nem no Clima, nem nos costumes, nem nos nativos; tem outro Corpo de Leis, outro Conselho para governar-Ihe, mas sempre com a finalidade de assemelhá-los: na Espanha Velha somente se reconhece uma casta de Homens; na Nova, muitas, e diferentes; na Velha dispõe da Real presença, nesta Nova veneramos igualmente seu Real Augusto Nome, tributamos as mais reverentes dádivas, sacrificando Vidas, Riquezas, e Corações, por manter todos a 
24

LORENZANA, Francisco Antonio. Historia de Nueva-España, escrita por su esclarecido conquistador Hernán Cortés, aumentada con otros documentos, y notas, por ...Arzobispo de México. México: Imprenta de Joseph Antonio de Hogal, 1770. (Edição fac-similar: México, Porrúa/SHCP: 1981. p.4-6).

\section{5}

LUHMANN, Niklas. Lo moderno de la sociedad moderna: complejidad y modernidad, de la unidad a la diferencia. Madrid: Trotta, 1998. p.133.

26

KOSELLECK, Reinhart. Historia/historia. Barcelona: Trotta, 2004.

27

Entre outros depoimentos, Koselleck evoca o de um amigo de Goethe ao escrever-Ihe em 1820: "Tem o senhor toda a razão, meu estimado amigo, no que diz sobre a experiência. Para os individuos sempre chega demasiado tarde, para os governos e os povos (a experiência) não está nunca disponível. Isso ocorre porque a experiência já realizada se expõe unificada em um núcleo e a que ainda está por realizar se estende em minutos, horas, dias, anos e séculos, de forma que o similar não parece nunca ser similar, pois em um caso só se considera o todo e no outro, partes isoladas". KOSELLECK, Reinhart. Futuro Pasado. Para una semántica de los tiempos históricos. Barcelona: 1993. p.339.

28

KOSELLECK, Reinhart. Historia/historia. Barcelona: Trotta, 2004. p.106. fidelidade sem a mais leve mancha; nos Espanhóis, herdada, e passada em sua substância com Leite, e nos Índios adquirida, alimentada com a Católica Religião, e aumentada com as Honras, Privilégios e Favores, com que sua Majestade, como tão grande, favorece a estes Párvulos, como tão Prudente a estes inocentes, como a tão Magnânimo a estes pusilânimes, e como tão rico, e Poderoso Monarca, a estes miseráveis: por isso, Espanhóis e Nativos são muito dignos da Real Piedade, e a que os Prelados Eclesiásticos cumpramos..."24 0 que ainda não está presente na percepção de Lorenzana é a dimensão temporal que caracterizaria propriamente a noção de experiência defendida por Koselleck e que começa a desenvolver-se no idioma alemão entre 1760 e 1780.

Em cada um se esconde uma experiência alheia transmitida institucionalmente de geração em geração. E o próprio da sociedade moderna radicaria em gerar sua identidade a partir do movimento que traça uma diferença com o passado. Rompe, nesse sentido, a seqüência natural da lembrança ao transformá-la em história. Cria sua identidade no âmbito da temporalidade. De acordo com Luhmann, isso não teria em si nada de extraordinário, pois nos termos da teoria de sistemas, um sistema autoreferencial - como o da consciência individual - constrói sua identidade a partir de uma referencia do passado, distinguindo o antes e o depois. ${ }^{25}$ Por esse motivo, o ponto decisivo para a investigação teórica e histórica estaria em saber como este procedimento referido aos indivíduos isolados passou a universalizar-se, a converter-se na experiência de uma sociedade.

Koselleck descobriu que a conjunção entre Geschichte e Historie ocorreu no idioma alemão entre 1760 e 1780, coincidindo também com o surgimento do neologismo "filosofia da história", cunhado por Voltaire. ${ }^{26}$ A história como acontecer e a história como conhecimento do passado se imbricaram, trazendo o embrião de uma nova relação com a temporalidade. Esta experiência se traduziu no reconhecimento paulatino de que já bem pouco se podia aprender da experiência adquirida. Em outras palavras, significava que o passado e o futuro se distanciavam um do outro: enquanto o horizonte de futuro se expandia, o espaço de experiência se estreitava. ${ }^{27}$ Nesse sentido, o conhecimento do passado entendido como acumulação de experiências úteis no presente ia dando lugar progressivamente ao neologismo "história contemporânea". Acontecer e conhecimento do passado se compactaram na palavra História (Geschichte). Assim, a identidade da diferença entre acontecer e acontecimento adquiriu a forma de um conceito singular universal: a História com maiúscula.

Neste contexto se desenvolveu um tipo de discurso histórico que funcionará como uma forma especular que permite ao presente reconhecer-se como diferente do passado ao mesmo tempo em que lhe diz o que fazer, o que não deixa de ser um paradoxo. A formação da "História como conceito-guia moderno" é observada primeiramente no interior da comunidade dos letrados, no cenário da linguagem política e social da vida cotidiana. ${ }^{28}$ Posteriormente, a história como conceito estruturante da nova sociedade mostra-a como uma entidade que aprendeu a articular-se a partir de uma linguagem temporalizada. Com a finalidade de dar sentido e orientação a experiências fundamentadas principalmente no futuro, desenvolveu uma nova linguagem histórica. Mas, sem deixar de esquivar-se do paradoxo inscrito no fato de que, ao mesmo tempo em que a escrita da história remete às coisas do passado para iluminar seu futuro, também está indicando que essas coisas deixaram de ser parte do presente. 
29

Ainda que não se possa omitir que no início desta análise se utiliza abertamente a um discurso histórico particularista ou "nacionalista".
30

Historiadores que ainda recorrem a explicações providencialistas encontrarão o problema de como conciliar vontade divina com liberdade ou vontade humanas.
31

A questão foi formulada na época por WHITE, Hayden: (¿se puede alguna vez narrar sin moralizar?) El contenido de la forma. Narrativa, discurso y representación histórica. Barcelona: 1992. Em "Historia y estructura", Michel de Certeau se perguntou igualmente pelo modo como se realizou a passagem de uma história como relação cronológica a uma nova história estruturada temporalmente. Em CERTEAU, Michel. Historia y psicoanálisis, entre Ciencia y Ficción. México, 2. ed., 2003. p.101-113.
Se aceitarmos, então, que os historiadores modernos, ao esclarecerem as relações do passado com o presente, trabalham com ao menos três tipos de conceitos (históricos, historiográficos e meta-históricos) propõe-se que a possibilidade de comparação está dada não tanto pela informação documental mas pelas categorias a priori utilizadas. São as que permitirão calibrar a especificidade e a diferenciação de cada um dos processos, além, logicamente, das relações dos processos com a língua própria.

Devido ao que foi dito, e com vistas à análise dos diversos processos examinados sobre a evolução do conceito História na América Ibérica, o mais significativo será poder mostrar, por um lado, as semelhanças (que podem expressar-se em um vocabulário compartilhado) e, do outro, as possíveis diferenças que permitirão especificar a singularidade de cada experiência. Esse ser diferente dentro do semelhante, seria o decisivo nesta pesquisa conjunta. 29

\section{HISTÓRIA E FORMAÇÃO DE UM NOVO ESPAÇO DE EXPERIÊNCIA NA AMÉRICA IBÉRICA}

$\mathrm{Na}$ apresentação dos resultados da pesquisa, em termos gerais, pode-se dizer que existe bastante coincidência em relação ao esquema conceitual proposto por Koselleck. Grosso modo é possivel dividir o periodo em três grandes etapas. Na primeira domina um conceito clássico de inspiração ciceroniana que entende a história como um gênero literário. Na segunda, estimulada principalmente pelos movimentos políticos e sociais, tenderá a assimilar a história nacional. A ruptura com o passado colonial e/ou com o passado não republicano estrutura novas narrativas históricas cujo sentido é dado principalmente por um futuro incerto, por um acontecer cujo desenlace é desconhecido pelos participantes. No entanto, a abertura de um novo espaço de experiência política não elimina automaticamente as formas de vida criadas no passado. Assim, como se mostra em alguns casos, o futuro pode ser lido também à luz de uma história providencialista. 30 Finalmente, em terceiro lugar temos o desenvolvimento de uma história universal ou filosofia da história, articulada a partir de noções como progresso e civilização.

No cenário luso-brasileiro, temos, durante a primeira metade do século XVIII, um conceito de história carregado de referencias clássicas e o centralismo da história sagrada. Depois, com uma referencia implicita à Revolução Francesa, se prolonga um período dominado pelo conceito ilustrado de história (1789-1823). Finalmente, o período subseqüente será marcado por uma nova complexidade, por novos debates, que fazem surgir novos dicionários e a necessidade de uma história nacional.

Poderiamos adiantar, então, que a transformação semântica da história passa pela reconfiguração dos projetos imperiais espanhol e português. Este momento, denominado como período de "transição", culmina durante os processos das independências. Nesta fase o vocábulo história se transforma em um singular coletivo. Uma das questões abertas, não obstante, será saber se - na construção das novas narrativas - modificam-se não apenas os conteúdos, mas também as formas. A questão é pertinente na medida em que, de acordo com os resultados, pareceria que o modelo ciceroniano continua sendo utilizado nesta "modernidade", se bem que em uma versão amplificada, dirigida à formação de uma nova cidadania republicana. ${ }^{31}$ 
Aristóteles. Poética. Buenos Aires: 2003. p.57. "Sobre o que foi dito se deduz também que não é tarefa de poeta relatar fatos que aconteceram, e sim o que pode acontecer, isto é, o que é possível segundo a verossimilhança ou a necessidade. 0 historiador e o poeta não diferem entre si porque um fala em prosa e o outro em verso, já que poderia pôr-se em verso as obras de Heródoto e não seriam por isso menos história do que são, mas diferem no fato de que um narra o que ocorreu e o outro o que pode ocorrer. Por isso a poesia é mais filosófica e elevada que a história, pois a poesia se refere mais exatamente ao universal e a história, por outro lado, ao particular. 0 universal consiste em que, a determinado tipo de homem the cabe dizer ou realizar determinado tipo de coisas segundo o verossímil ou o necessário. A isso aspira a poesia, ainda que imponha nomes pessoais. 0 particular, por sua vez, consiste em dizer, por exemplo, o que realizou Alcibiades e que coisas sofreu".

33

Cicero. De Oratote (46 a C): "Historia vero testis temporum, lux veritatis, vita memoriae, magistra vitae, nuntia vetustatis, qua voce alia nisi oratoris immortalitati commendatur? Nam si qua est ars alia, quae verborum aut faciendorum aut legendorum scientiam profiteatur; aut si quisquam dicitur nisi orator formare orationem eamque variare et distinguere quasi quibusdam verborum sententiarumque insignibus: aut si via ulla nisi ab hac una arte traditur aut argumentorum aut sententiarum aut denique discriptionis atque ordinis, fateamur aut hoc, quod haec ars profiteatur, alienum esse aut cum alia aliqua arte esse commune".

\section{4}

Voltaire. El siglo de Luis XIV. México: 2a. reimpressão, 1996. p.7 e p.10. KOSELLECK, Reinhart. Futuro Pasado. Para una semántica de los tiempos históricos. Barcelona: 1993. p.48-49.

35

Ver como exemplo AYLUARDO, Clara García. Los Borbones y la Nueva España: El otro yo del Rey: Virreyes de la Nueva España, 1535-1821. México: 1996, p.43-57. A representatividade deste texto se apóia em seu caráter de divulgação.

36

Se quer ver modernidade onde só se trata de reformas modernizadoras. "A revisão do governo imperial realizada pelos Bourbons pode ser considerada uma centralização do mecanismo de controle e uma modernização da burocracia. A criação de novos vice-reinos e de outras unidades de governo aplicou uma planificação central a um conglomerado de unidades administrativas, sociais e geográficas e culminou na nomeação de intendentes, agentes fundamentais do absolutismo" (89). Sem mudar as condições de dominação "modificou o caráter do Estado Colonial e o exercício do poder" (91). Mas poderia ser, se sugere, que tal política de centralização e planificação extremadas tivesse um efeito paradoxal involuntário, por não obedecer à tradição, por ignorar e repudiar o passado, como aponta Lynch (91). "Os Bourbons procederam como se pudessem deter a história, inverter o desenvolvimento de uma comunidade e reduzir pessoas adultas à categoria de subordinados" (91-2). LYNCH, John. El Estado Colonial en Hispanoamérica: América Latina, entre colonia y nación. Barcelona: 2001.

\section{Os dicionários e a língua: predomínio da história-narração}

Valdei Lopes de Araújo e João Paulo Garrido Pimenta anotam algo sobre o uso dos dicionários que convém reter: estes não retratam o uso da linguagem no momento em que aparece, mas apenas tendem a estabilizar o resultado de uma disputa lingüistica prévia. A respeito do conceito "história", chama a atenção, por exemplo, que os dicionários não detectam sua transformação antes de 1850, e, inclusive, nem no final do século XIX, como se destaca no caso espanhol.

Em principio sobressai o aspecto distintivo da história: seu caráter narrativo, e portanto, literário, assim como sua vocação de edificação moral. Ao menos até as duas primeiras décadas do século XIX continuam sendo evocadas duas das autoridades intelectuais pertencentes ao mundo clássico greco-latino: Aristóteles ${ }^{32}$ e Cícero ${ }^{33}$. É provável que durante esse periodo apareçam manuais que recordam e exigem o respeito às regras para obter a verdade da história. A regra é aperfeiçoável. Mas, em geral, a natureza moral da história não é posta em dúvida. Inclusive, Voltaire criador da noção de "filosofia da história", em dívida com Bossuet - espera obter da história uma lição de moral para o presente. A Historie continua sendo concebida como o repertório de experiências alheias, úteis para os momentos e a tomada de decisões difíceis. Nesse sentido à história relatada cumpre também uma função político-moral. Se bem que começa a notar-se que só alguns séculos podem cumprir esta função, como o "século de Luis XIV". Com isso observa-se uma demarcação do passado, mesmo que sem afetar a estrutura narrativa que articula o discurso histórico. "Nem todo o acontecido merece ser escrito. Nesta história me interessarei somente pelo que merece a atenção de todos os tempos, que pode descrever o caráter e os costumes dos homens, servir de exemplo e fomentar o amor à virtude, às artes e à pátria", escreveu Voltaire. ${ }^{34}$

\section{Reformas Imperiais, Ilustração e História}

Tendo em conta o que foi dito anteriormente, a pergunta consiste em: quando e em que contexto a história se constituiu em uma denominação abstrata, universal, e ao mesmo tempo singular? Mais precisamente, a pergunta pode ser formulada assim: em que momento e em que contexto o passado e o futuro se coordenaram de maneira tal que se tirou da Historie seu poder de exemplaridade? Trata-se de uma questão relacionada com a produção de textos de história, mas, talvez, principalmente, com a forma como os agentes iam percebendo o acontecer.

É comum associar as Reformas Bourbônicas com a "modernidade" ilustrada, ${ }^{35}$ sem perceber, muitas vezes, seus paradoxos. ${ }^{36}$ Ao referir-nos ao conceito de história, sublinhou-se seu caráter experiencial. Trata-se, antes e mais nada, de um conceito de temporalidade cuja explicitação só se consegue recorrendo a metáforas espaciais de movimento, aceleração etc. Teriamos que ver, portanto, como os Bourbons e seus funcionários estavam experimentando o tempo, o como este se refletia em seus projetos, para poder vê-los como representantes genuínos da formação de um novo espaço de experiência.

Assim, devemos transladar-nos ao espaço literário onde a produção de histórias acontece durante este período. Nesse sentido talvez seja mais relevante observar a criação de diversas Academias dedicadas às Belas Artes e à História fundadas durante a segunda metade do século XVII na França; e na Espanha (1735), Portugal e Brasil (1720) e em outros lugares durante a 
Ver GRAFTON, Anthony. Los orígenes trágicos de la erudición. Breve tratado sobre la nota al pie de página. Buenos Aires: 1998.

\section{8}

Ver, GRELL, Chantal. L'Histoire entre érudition et philosophie. Étude sur la connaissance historique a l'age des Lumières. Paris: 1993. Para a Espanha, MARTí-AGUILAR, Manuel Álvarez. La Antigüedad en la historiografía española del s. XVIII: el marqués de Valdeflores. Málaga: 1996.

39

VOLTAIRE. El siglo de Luis XIV. México: 2a ${ }^{\text {a }}$ reimpressão, 1996. p.357.

\section{0}

"...considerando o grande número de nações, costumes e religiões diferentes, se nota o pouco que representam sobre a Terra um molinista e um jansenista. Qualquer pessoa se envergonha, então, de sua paixão veemente por uma seita que se perde entre a multidão e a imensidão das coisas", VOLTAIRE. El siglo de Luis XIV. México: $2^{\text {a }}$. reimpressão, 1996. p.440.

41

Análogo à moda atual em relação ao uso do termo "moderno".

\section{2}

Pedro José Chacón Delgado, (Espanha).

\section{3}

As Reformas Bourbônicas tiveram impacto no caso argentino com a criação do Vice-reinado do Rio da Prata em 1776. Trata-se de um fato político e administrativo de grande relevância que inclui a criação do orbe literário e a publicação dos primeiros jornais por volta do ano 1800 (El telégrafo). Mesmo que não se possa desconsiderar que continua dominando a taxonomia aristotélica que diferencia a história saber do particular -, da poesia - saber do geral - ao menos no meio eclesiástico, como se pode ver em um testemunho de 1802. segunda metade do século XVIII. Contudo, por sua criação se pode observar não uma transformação semântica da história, mas sim o aprofundamento de uma prática de crítica textual renascentista ao fazer extensivo o combate às histórias fabuladas desde o século XVII. ${ }^{37}$

Por outro lado, as Academias podem ser vistas como um espaço onde o cultivo das artes e das ciências deixou de ser patrimônio exclusivo dos monarcas ao incentivar a pesquisa e a conservação da Antigüidade. 38 Além disso, sua formação permitiu o desenvolvimento paralelo da física ou história natural, e de uma história "ajuizada" do gênero humano. 39 Ao que foi dito anteriormente teríamos de acrescentar a expansão da imprensa jornalística, iniciada na Grã-Bretanha no século XVII e em pleno desenvolvimento no contexto ibero-americano a partir do século XVIII. A imprensa escrita proporcionou um espaço de comunicação apropriado para desenvolver a arte da comparação entre diversas culturas e para mostrar que nem toda a história era redutivel a ações individuais, por mais importantes que fossem. 0 incremento de informação sobre a vida e a situação de outros povos e culturas permitiu desenvolver também um olhar irônico sobre sua realidade e seu presente. A contemplação da "história geral do mundo" mostrava que as disputas locais não eram tão determinantes como poderiam parecer à primeira vista. 40

Portanto, quem dispunha de uma visão cosmopolita tinha um "espírito ilustrado", termo em moda na época em que se punham em prática as famosas reformas promovidas pelos Bourbons, durante a segunda metade do século XVIII. ${ }^{41}$ A experiência de viagem, o desenvolvimento da imprensa jornalística e o espírito interrogativo universalista estão presentes em um dos produtos mais emblemáticos da "Ilustração": a Encyclopedie (1751) de Diderot e D'Alambert. E é verdade, como se destaca no caso ibero-americano, que esta marca distingue um letrado tão influente como Gregorio Mayans y Siscar. Como leitor da Enciclopédia, um ano depois de seu lançamento, Mayans divide a história em humana e sagrada; e a humana, por sua vez, em literária, natural e civil. ${ }^{42}$ Sobre esta base se desenvolve 0 estudo do passado, que inclui a revisão das origens do Império no século da conquista. Corrigem-se e escrevem-se novas, mas no fundamental se fazem para atualizar esse passado glorioso, para fazer um chamamento à unidade dos mundos tão diversos que o compõem, e confirmar, sobretudo a dinastia reinante em um momento de mudança. ${ }^{43}$

A importância da história natural e o surgimento da história universal ou "história sem mais", inaugurada por Bossuet e continuada por Voltaire, fazem referência à formação de um novo campo de experiência? Não necessariamente, no sentido de oferecer uma nova maneira de coordenar as relações entre passado e futuro. É verdade que durante a segunda metade do século XVIII numerosas expedições científicas foram realizadas. A Coroa espanhola envia funcionários civis e eclesiásticos para supervisar e reestruturar as fronteiras geográficas e culturais de seus domínios. No caso da Argentina, Félix de Azara (Descripción e historia del Paraguay y del Río de la Plata, 1790); Chile, Vicente Carvallo y Goyeneche (Descripción histórico-geográfica del Reino de Chile, 1795); México, Alejandro de Humboldt, (Ensayo político sobre el reino de la Nueva España, 1805); Venezuela e Colômbia, José Gumilla (El Orinoco ilustrado y defendido, 1741) e Alejandro de Humboldt (Viaje a las Regiones Equinocciales del Nuevo Continente, 1816- 1826). No caso da Coroa portuguesa, Damião de Lemos Faria Castro, 
44

Chile: MOLINA, Juan Ignacio. Compendio de la Historia Civil del Reyno de Chile. Colômbia: GILIJ, Felipe Salvador. Ensayo de Historia Americana, Estado presente de la Tierra Firme.; México: CLAVIJERO, Francisco Javier. Historia antigua de México. 1780. A "modernidade nacionalista" as acolherá como precursoras das novas histórias.
45

Ver o livro de CAÑIZARES-ESGUERRA, Jorge. How to Write the History of the New World. Histories, Epistemologies, and Identities in the Eighteenth-Century Atlantic World. Stanford: 2001. Fica a impressão de que seu percurso ainda está codificado pelo selo nacionalista. Nesse sentido não consegue ser um texto de genuína crítica pós-colonial. Dá continuidade, em boa parte, a uma épica crioula construida ao redor de uma história das idéias.
(História geral de Portugal e suas conquistas oferecida à Rainha Nossa Senhora D. Maria I, 1786-1804). Os escritos dos antepassados são revisados e as histórias já escritas são retificadas.

As monarquias espanhola e portuguesa, é verdade, olham para si mesmas diante do futuro; mas se pensa neste futuro mais em termos de conservação e continuidade, não tanto de transformação. Igualmente, as histórias naturais em sentido estrito não são tarefa de "historiadores". A história em conjunto, das artes e ciências do período, é apenas um saber particular que cumpre uma função geralmente associada à perfectibilidade do gênero humano. Inclui uma perspectiva de futuro, mas trata-se de um porvir que se reconhece ainda no passado. Trata-se essencialmente de um "futuro passado" capaz de ser recriado por obra dos historiadores. A história como gênero literário, nesse sentido realiza um trabalho paralelo ao dos naturalistas.

A marca "enciclopedista" de Mayans se percebe especialmente na década de 1780. Reflete-se na necessidade de programar uma história da nação espanhola incluindo todos os seus territórios. E, curiosamente, quem realiza esta tarefa, em alguns casos, são jesuitas que foram expulsos dos domínios da Monarquia em $1767 .{ }^{44}$ Surgem sob signo da polêmica, ao questionar as histórias críticas ilustradas de autores como o Abate Guillaume-Thomas Raynal, Histoire Philosophique et Politique des établissements et du comerce des Européens dans las deux Indes (1770); William Robertson, The History of America (1777) e Cornelius de Pauw, Recherches philosophiques sur les américains, ou Mémoires intéressants pour servir à I'histoire de l'espèce humaine (1768-69). Apoiados na figura da testemunha presencial como autoridade, argumentam contra as narrativas históricas que denigram as nações de raízes ibero-americanas. Aí começa a prevalecer, como se destaca também para os casos metropolitanos (Madri e Lisboa), a história civil.

No final do século XVIII, o caráter narrativo da história continua dominando. Essa forma, no entanto, começa a ser afetada pelas reformas disciplinares impulsionadas por autores como Gaspar Melchor Jovellanos (Sobre la necesidad de unir al estudio de la legislación el de nuestra historia, 1780), Juan Pablo Forner (Discurso sobre el modo de escribir y mejorar la historia de España, c.1788) e Juan Sempere y Guarinos (Reflexiones sobre el buen gusto en las ciencias y en las artes, 1782). 45 Como pano de fundo se destaca a figura de Francis Bacon e seu Novum Organum. Esta marca é visivel no contexto americano no Mercurio Peruano (1791-1795), e mais tarde (traçando uma linha de continuidade entre um século e outro) em José Manuel Valdez y Palacios (Bosquejo sobre el estado político, moral y literario del Perú en sus tres grandes épocas, 1844). 0 Mercurio faz eco a Jovellanos: "Em nossas crônicas, histórias, anais, compêndios e memórias (...) se encontram, sim, guerras, batalhas, comoções, fome, pestes, desolações, portentos, profecias, superstições (...) Mas, onde está uma história civil, que explique a origem, progressos e alterações de nossa constituição, nossa hierarquia política e civil, nossa legislação, nossos costumes, nossas glorias e nossas misérias?" Assim, para o caso do Peru, mas talvez também para outras das antigas colônias, não é fácil separar o desenvolvimento da história na América da história peninsular. 
46

VISCARDO Y GUZMÁN, Juan Pablo. La paz y la dicha del nuevo siglo. Exhortación dirigida a todos los pueblos libres o que quieren serlo, por un americano español. (1797). Obra completa em dois volumes (Lima: Congresso del Perú, 1998).

47

Idem. Ensayo histórico sobre los disturbios de América Meridional en el año 1780. In: La paz y la dicha del nuevo siglo. Exhortación dirigida a todos los pueblos libres o que quieren serlo, por un americano español. (1797). p.43-57.

\section{8}

Valiosos testemunhos da recepção e utilização da Carta se encontram no volume 2 das Obras Completas de Viscardo. Idem. Obra completa. Lima: Congreso del Perú, 1998.

\section{9}

Idem. Carta a los españoles americanos (Tradução do manuscrito francês encontrado em Nova York), 1799. In: ______. Obras completas. p.205. (ressaltado no original).

\section{Interlúdio político e intelectual}

As obras históricas de filósofos ilustrados como Raynal e Robertson reapareceram depois dos acontecimentos de 1789, mas em um contexto político diferente. Esta situação refere-se não só à queda da Bastilha, mas também à independência das 13 colônias inglesas da América (1776). A evocação de tais acontecimentos contém a carga de um futuro possivel. Este passado imediato diz como poderia ou deveria ser o porvir. Tal consideração faz parte da argumentação de outro jesuíta expulso, originário de Arequipa, no Peru, mas situado em Londres e não na Itália, Juan Pablo Viscardo y Guzmán. Viscardo morreu em Londres, em fevereiro de 1798, sem ter visto publicada sua famosa Carta a los españoles americanos em 1799. Seu conteúdo é inspirado, por um lado, na obra do clérigo menorista Raynal e, por outro, escreve-a pensando no século que acabava de começar. Como filho de espanhol nascido em solo americano, Viscardo se identifica com a causa empreendida pelos colonos norte-americanos: a partir desse ponto de vista, cogita a possibilidade de independência das colônias hispanoamericanas por meios pacíficos. ${ }^{46} \mathrm{Em}$ seu discurso assume injúrias cometidas durante os distúrbios de 1780 na América Meridional. ${ }^{47}$ A Carta é famosa porque será difundida e utilizada a partir de 1799 pelo General Francisco Miranda, instalado também, como Viscardo, em Londres, e mais tarde na Venezuela, durante a guerra de independência a partir de 1810.48

Viscardo argumenta historicamente ao mostrar que o Império espanhol não estava se comportando à altura, tomando como modelo a relação que os gregos estabeleceram com suas colônias. Neste procedimento, a história é ainda um depósito de experiências úteis para o presente. No entanto, nesse contexto letrado, o que chama a atenção é a forma como se refere aos três séculos de presença da Espanha em solo americano. Permito-me citá-lo por extenso, devido à sua importância:

\footnotetext{
A proximidade em que nos encontramos do quarto século desde que nossos ancestrais começaram a estabelecer-se no Novo Mundo é um acontecimento notável demais para não atrair mais seriamente nossa atenção. 0 descobrimento de tão grande parte da Terra é, e será sempre para o gênero humano, o acontecimento mais memorável em seus anais; mas para nós que somos seus habitantes, e para nossos descendentes, é um tema de suma importância. 0 Novo Mundo é nossa Pátria, sua história é a nossa, e é nela que todos nossos deveres essenciais, nossos mais caros interesses, nos obrigam a examinar e a considerar atentamente o estado de nossa presente situação e as causas que nela mais influiram, para resolver-nos logo, com pleno conhecimento, a tomar valentemente partido que nos ditarão nossos indispensáveis deveres para com nós mesmos e nossos sucessores.

Apesar de que nossa história de três séculos, no que diz respeito às causas e efeitos mais dignos de atenção, seja tão semelhante e conhecida a ponto de poder ser abreviada nas quatro palavras seguintes: Ingratidão, Injustiça, Escravidão e Desolação, nos convém lê-la mais detidamente. ${ }^{49}$
}

Se não me equivoco, inspirado no texto de Raynal, Viscardo está inaugurando o tema dos 300 anos de opressão que reverberará de muitas maneiras nas duas décadas seguintes: como slogan dos insurgentes americanos e como uma frase inscrita nas atas de independência. 0 mais relevante, não obstante, consiste em que esse passado tri-secular perdeu seu caráter de exemplaridade, mostrando um estreitamento do espaço de experiência ao lado de um alargamento do horizonte de expectativas, em termos políticos e sociais. Essa nova relação entre o passado e o futuro se sustenta, como foi dito, nos eventos fundadores de 1776 e 1789. 
Utilizado por Frei Servando de Teresa de Mier no México. Cf. BRADING, David. Orbe indiano. De la monarquía católica a la república criolla, 14921867. México: 1991. p.638-640.
Victor Samuel Rivera (Peru)
Tal consideração não deixa de lado o fato de que muitos destes impressos e manuscritos foram proscritos e acossados pela inquisição no México, 50 e no Peru só foram conhecidos depois de 1824. Assim, temos de acrescentar que muitos destes textos não começam a ter relevância até depois das independências. Ainda se conhece pouco - salvo algumas exceções - sobre seu impacto entre os contemporâneos. Talvez Viscardo seja uma das exceções: sua Carta foi utilizada desde Londres para alentar e promover a idéia de independência, seguindo o exemplo anglo-americano, favorecida estrategicamente pelos britânicos. Viscardo se relaciona com os trabalhos de Clavijero e outros jesuitas expulsos somente no aspecto de combater os preconceitos europeus sobre o continente americano. Para isso continuam recorrendo a um antigo principio de autoridade: a figura da testemunha presencial do que se narra. 0 testemunho de Viscardo coincide também com o clima intelectual da época. Por volta de 1800, na Europa, não se fala de um novo renascimento, e sim do começo de algo novo, sem precedente no passado.

No entanto, quanto à argumentação histórica, oscila-se entre a evocação dos fatos remotos da Antigüidade clássica e os contemporâneos. E a história continua sendo, essencialmente, mais um conceito moral que político, que pressupõe a diferença com a história natural, já que nesta última se desconhece o livre-arbitrio. Esta noção de história civil ou moral inclui, portanto, a noção de perfectibilidade, regulada por modelos preestabelecidos, que convidam à imitação mais que à modificação da história. Só o humano é perfectível, diferentemente da história sagrada, que é perfeita por natureza divina. Esta noção tenderia a fraturar-se durante o século XVIII alemão, quando a Bíblia e a teologia se converteram em objetos da análise histórica; quando Herder declarou que a Bíblia tinha também uma história. Por outro lado, no contexto ibero-americano, a fratura proviria mais exatamente de eventos politicos e sociais que propriamente intelectuais. Nesse sentido, é verdade que no contexto ibero-americano não se tem à mão uma elaboração crítica de uma noção de história como Magistra vitae, e, por conseguinte, não seria concebivel a abertura de um novo espaço de experiência. ${ }^{51}$ Ainda que poderíamos pensar na conveniência de ampliar o repertório de fontes utilizadas para verificar tal afirmação. Em todo caso parece ser que todos os casos tratados estão unidos por um denominador comum: não tanto a Revolução Francesa e o movimento da llustração em si, mas os efeitos das guerras européias desatadas por Napoleão nos domínios ibero-americanos. Suas repercussões serão ainda mais notáveis a partir de 1820: o círculo da narratologia histórica clássica tenderia então a romper-se.

\section{Os processos de independência e "os $\mathbf{3 0 0}$ anos de opressão"}

Recordando a hipótese central que emoldura esta pesquisa, Koselleck aponta que houve um momento no qual se observa, no idioma alemão, uma interseção lingüística. Há um lapso em que se cruzam a Geschichte - a história como acontecer refletida nos fatos sucedidos (Ereignis) - e a Historie, entendida como relatório e representação verbal ou escrita dos fatos sucedidos. A história como saber das coisas do passado para ilustração do presente (Magistra vitae) se funde com o próprio acontecer, de tal modo que o futuro tende a nutrir-se do presente, mais que do passado distante. A fusão do acontecer com o saber no presente se manifesta no 
52

A respeito, ver o sugestivo estudo de PIMENTA, João Paulo Garrido. Brasil y las revoluciones de Hispanoamérica (1808-1822). In: CALDERÓN, María Teresa; THIBAUD, Clément (Org.). Las revoluciones en el mundo atlántico. Bogotá: Taurus, Universidad Externado de Colombia, 2006. PIMENTA, João Paulo G. . Brasil y las independencias de Hispanoamérica. Castelón: Publicacions de la Universitat Jaume I, 2007. p.13-29.

53

Que implicaria tal elaboração? É uma questão aberta. Existe, por enquanto, a proposta de CAÑIZARES-ESGUERRA, Jorge. How to Write the History of the New World. Histories, Epistemologies, and Identities in the Eighteenth-Century Atlantic World. Stanford: 2001. E evidentemente as versões nacionalistas amplamente difundidas da "intelectualidade crioula" como precursora da independência.

54

Cf. LYNCH, John. Las raices coloniales de la independencia: América Latina, entre colonia y nación. Barcelona: 2001. Se bem que Lynch esclarece ao declarar que nos anos prévios às independências a "consciência política" vinha mudando (p. 163).

55

Angel Rafael Almarza Villalobos, (Venezuela).

56

BREÑA, Roberto. El primer liberalismo español y los procesos de emancipación de América, 1808-1824. Una revisión historiográfica del liberalismo hispánico. México: 2006. p.225-235.

\section{7}

Desenvolvi essa situação mais amplamente em meu artigo jornalístico "Apropiación del pasado, escritura de la historia y construcción de la nación en México". termo Geschichte, que deixa para trás a forma plural das Historien e se converte em um singular universal. Este fenômeno ocorreu de maneira mais tangivel ao redor do ano 1800. Retrospectivamente, poderia aparecer apenas como um interlúdio quanto à proximidade que alcança a história com a filosofia ou a poesia. Independentemente disso, o mais importante na tese de Koselleck reside no fato de que com o aparecimento do neologismo História (Geschichte) (que implica ao mesmo tempo saber da história e fazer a história) aparece também a formação de um novo espaço de experiência conhecido como "moderno".

Em geral, haveria coincidência em que esta mudança ocorreu no meio ibero-americano entre 1808 e 1823, propiciado não tanto por um movimento intelectual como por movimentos sociais e políticos que originaram a desarticulação do império espanhol e português. 52 Assim, as mudanças políticas são o que move a transformação semântica da história, sem que exista uma elaboração intelectual previa. 53

É evidente ainda que a cronologia desta transformação não é a mesma para cada uma das regiões examinadas. À luz de uma história econômica e das idéias, por exemplo, as mudanças sociais situam-se basicamente durante o período das reformas bourbônicas. Estas medidas presumivelmente teriam rompido os laços sociais entre diversos grupos e produzido um novo tipo de "colonialismo", o qual seria a causa direta dos processos de independência. 54 É inegável que esta descrição coincide com o projeto de Viscardo y Guzmán, inspirado em autores como Raynal, Montesquieu e Thomas Paine. Mas a questão que já não é tão clara é a relação entre este argumento e o curso das ações que originaram o desmoronamento do império espanhol e português. Se a análise ideográfica permite vislumbrar uma linha de continuidade entre o periodo das reformas bourbônicas e o das independências, ao contrário, uma análise histórica conceitual mostra, mais exatamente, que há razões suficientes para pensar que somente a partir de 1808, com as Cortes de Cádiz (como efeito da invasão francesa da Espanha), aflora a possibilidade da criação de um novo espaço de experiência com implicações em novos usos da temporalidade. A história, a partir de então, parece passar mais rápido, e assim os padrões clássicos de calcular o tempo tendem a se tornar obsoletos. Seria um momento em que as relações entre passado e futuro se deslocam, passam a ser discordantes.

No caso da Venezuela há expressões sintomáticas desta mudança. Miguel José Sanz, amigo de Francisco de Miranda, utiliza em 1810 a metáfora da orfandade para descrever a situação da nação: ficaram sem pais e, portanto, sem a tutela natural. Em um diário de 1811 pode ler-se a expressão formulada por Viscardo e disseminada por Miranda sobre o império que exerceu sua dominação com grande "ferocidade por mais de 300 anos". Esta fórmula entra na moda durante as guerras de independência até ficar consagrada, em alguns casos como o da Venezuela e México, na Ata constitucional. 55 E é possivel, surpreendentemente, encontrar esta expressão dos "300 anos" no campo "contrário" ainda que com outra carga de valor. 0 espanhol Francisco Martínez Marina, representante nas Cortes de Cádiz, em dois textos, de 1808 e 1813, se volta para o passado espanhol para resgatar tudo o que de bom nele encontra para construir uma monarquia republicana. ${ }^{56} 0$ exposto nos indica duas coisas: 1) o passado tornou-se ambíguo e 2) sobre um duplo anacronismo de sinal contrario se está erigindo um novo regime de historicidade. 570 passado refletido no presente como um espelho começou a rachar. 
58

SCHMIDT, Peer. Siéndome preciso no perder minuto. Percepción del tiempo en México (18101910). datilografado inédito.
59

Na linha seguida por João Paulo Pimenta: "Dito de outra forma, defendo que a criação de uma idéia de história do Brasil, com traços especificos em relação à história de Portugal, foi um dos motores do desenvolvimento e viabilização do projeto político da independência". Em "Espacios de experiencia y narrativa historiográfica en el nacimiento del Brasil independiente (Apuntes para un estudio)". In: Brasil y Las Independências de Hispanoamerica. Castelló de La Plana: Publicacions de La Universitat Jame I, 2007.p. 135.
Não obstante, esta situação apresenta um paradoxo. Os três séculos que precedem 1789 não pertencem aos tempos modernos, são algo que se apagou. Este "virar a página" indica a anulação do passado como um passado exemplar, e o predomínio do presente orientado para um futuro que serve de modelo. Aponta para a formação de um espaço de experiência que não germinou fundamentalmente no campo das letras e sim no terreno da formação de uma nova linguagem política e social. Esses "300 anos" não se parecem em nada ao que acaba de nascer e seu desenlace é incerto para a maioria dos seus agentes. Nesse sentido, aquilo que vai tomando forma só se parece a si mesmo. Instala-se um cenário em que a história está como que suspensa.

Durante este periodo se mostra também - como já acontecia desde o verão de 1808, diante dos eventos da abdicação de Carlos IV e Fernando $\mathrm{VII}$-, que as autoridades em diversas capitais de vice-reinos demonstram nervosismo diante da aceleração dos eventos e da falta de informação sobre o que está ocorrendo na Europa. Há testemunhos em que se manifesta que a experiência acumulada de vários séculos deixou de ser funcional para o presente, uma atualidade que se projeta em termos de horas, dias, anos. Expressões desse estado de ânimo se encontram na Historia de la revolución de Nueva España de Frei Servando Teresa de Mier ao utilizar freqüentemente o termo aceleração e seus sinônimos. Outro testemunho de 1813 exclama: "O grito de liberdade que se deu em Dolores na noite de 15 a 16 de setembro de 1810, pelo imortal herói D. Miguel Hidalgo y Costilla, se propagou com a rapidez de um raio por todos os confins do venturoso Anáhuac, que se encontrava sepultado em duro cativeiro quase por três séculos".58 Assim, as observações de Peer Schmidt coincidem com a hipótese geral deste ensaio: a abertura de um novo espaço de experiência se vincula diretamente às mudanças políticas e sociais que emergem com os movimentos de independência. Este comentário é relevante na medida em que, durante o período anterior, a história se deve, sobretudo, às letras, à literatura, à educação do príncipe e de sus súbditos.

No entanto, não devemos esperar que a formação desta nova experiência do tempo se generalize com a mesma "velocidade de um raio" ao todo social. É fácil então limitar esta experiência a um pequeno grupo de funcionários e ativistas políticos, sociais e militares. De outra forma estes setores não teriam se preocupado relativamente cedo em empreender campanhas de "moralização" para construir um novo tipo de cidadania, para generalizar essa experiência. Tal ímpeto "civilizatório" mostra essencialmente que se trata de um projeto de futuro. E simultaneamente se tentará descobrir no passado aquelas "experiências" análogas às do presente. É o momento em que as trajetórias das sedes imperiais e coloniais tenderão a bifurcar-se. 59 Cada uma das sedes metropolitanas e subalternas construirá, à sua maneira, uma plataforma que restaure ou invente de novo a imagem especular da história. Trata-se já de gestos modernistas: o passado é mobilizado em função de um futuro aberto, cujo desenlace é desconhecido igualmente por cada um dos participantes. Esta nova experiência talvez não impeça a sobrevivência da velha história. Regressa a história como espelho do presente, mas seguramente com novos conteúdos. A pergunta é saber se este movimento implica também na transformação das formas de registrar a história.

\section{Surgimento e predomínio da história contemporânea}

No contexto das crises imperiais, se desenvolve o neologismo histórico de história contemporânea. Enquadrada pela crise política e social, aparece 
No caso peruano, cf. Javier Fernández Sebastián, artículo sintesis sobre liberal/liberalismo.

61

Por exemplo, o espanhol DE LA ROSA, Francisco Martinez. ¿Cuál es el método o sistema preferible para escribir la historia? Revista de Madrid, segunda serie, tomo II, 1839.

62

DE LA ROSA, Francisco Martínez. El Espiritu del Siglo. Madrid: BAE, 1960-62 (vols. V-VIII), (citações tomadas de Manuel Moreno Alonso:1979.) uma noção que se percebe no México, Argentina e inclusive no Peru já em 1812: a história dos últimos anos é mais generosa em lições que toda a história anterior. 60 Sua presença no vocabulário da época é um sintoma da distância que separa seus porta-vozes da experiência de outros tempos, revelando a perda de aura das histórias remotas, clássicas, renascentistas ou medievais. Esta nova experiência, por sua vez, vai estabelecendo as bases para o surgimento do passado como objeto de pesquisa, um passado que já não é capaz de modelar o presente, mas sim susceptível de ser conhecido. Assim, é importante observar - como se pode constatar em vários autores, peninsulares e não peninsulares -61 que paulatinamente a única história capaz de ensinar algo é a história contemporânea, principalmente as histórias de caráter político e militar. "Ai da América se não aproveita o estudo da história contemporânea!", lê-se em um semanário mexicano de 1826. Ou na Espanha: "a história dos últimos cinqüenta anos contém mais lições de política que a longa série de muitos séculos; mas se pode afirmar, sem temor de ser desmentido, que se as nações aprenderam pouco na escola da adversidade, menos talvez aprenderam os governos. Não é estranho que se ouçam com indiferença as severas lições da história, e que procurando justificativas na diversidade dos tempos e de circunstâncias, não se faça a devida aplicação de verdades muito importantes, mas que se esqueçam tão rápido alguns desenganos tão amargos; que se fechem os olhos para não ver os fatos que estão ocorrendo à nossa vista, e que em vez de manifestar a causa de tantos males para aplicar o remédio oportuno, se queira perpetuar os antigos males, dificilmente parecerá aceitável para a posteridade".62

A ascendência da história contemporânea, amplificada pelo surgimento de "histórias filosóficas", transformou-se em tribunal de justiça do próprio processo, abrindo uma fenda crescente entre o passado tido como autoridade e o presente estabelecido como potestade de si mesmo. Tratase de um novo programa de história que afeta especialmente a esfera da história civil e política, e portanto, que acompanhará de perto a construção e ressemantização de outros conceitos, como o de nação. Este programa, por sua vez, requererá a formação de um novo tipo de relato histórico e, portanto, de um programa de formação de um novo tipo de historiadores a serviço da nação. Tal necessidade se faz explícita por volta de 1850, por exemplo, na Argentina - na voz de Bartolomé Mitre ao fundar o Instituto Histórico e Geográfico do Rio da Prata.

\section{A história como conceito político}

A partir de 1820 se generaliza a noção de história como conceito político. Nada simboliza melhor este fato que a autocoroação de Napoleão em 2 de dezembro de 1804 na igreja de Notre Dame: sua autoridade emana de si mesmo e tem como espectadores apenas as autoridades tradicionais (dinastia, herança, papado). A selfmade history tem o poder de inaugurar uma nova tradição dinástica. Dado que o passado deixou de informar o presente, que os modelos tradicionais do "fazer" e do "dever ser" foram desativados pela nova realeza, é necessário dotar de leis e autoridade (legitimação) o novo Estado. Surgem o código civil, penal etc. 0 espírito reformista informa a sociedade e se faz necessária a Constituição. Ao mesmo tempo se inaugura um novo regime de historicidade (Hartog). Mas, como foi sugerido, trata-se apenas de uma das facetas do processo. Será necessário examinar como esta "modernidade" está sendo incorporada pelos dife- 
63

BARQUERA, Juan Maria Wenceslao. Lecciones de politica y derecho público para instrucción del pueblo mexicano. México: edição fac-similar, 1991.
Citado por CHACÓN, Pedro José. El concepto de Historia en España (1750-1850). Araucaria, n.17, p.15. 2007 rentes setores sociais. 0 decisivo, em qualquer caso, consistirá em perguntar como os diversos agentes vivem e processam a história de agora em diante.

$\mathrm{Na}$ América lêem-se os autores espanhóis, mas essas leituras se enriquecem também com as próprias, geralmente escritas fora do país. Na produção de idéias e, conseqüentemente, no debate conceitual, domina a história civil e eclesiástica, alimentada desde o século XVIII pelo desenvolvimento da imprensa jornalística. Mas a história, apesar de ser importante, não parece ter uma centralidade tal como começará a ser observado a partir da crise dos regimes imperiais, no principio da década de 1820. Desde então se dota o vocábulo história de um poder quase demiúrgico, só equiparável ao que pode continuar tendo a pastoral eclesiástica. Este novo poder da história está documentado em um texto publicado no México, em 1822.63 Nele se estabelece que não há boa política sem história e viceversa. Este axioma, é verdade, recorda o Jovellanos de 1780, ao admitir que o bom funcionamento da política repousa no conhecimento do direito e da história.

A partir de então há um redimensionamento da história integrado cada vez mais no vocabulário político e social. Esta tendência culmina, como se mostrou em outros casos, na escrita de uma história nacional canônica: Brasil: Francisco Adolfo de Varhagen,História Geral do Brasil (1854-1857); Colômbia: José Manuel Restrepo, Historia de la Revolución en Colombia (1827); Chile: Claudio Gay, Historia fisica y politica de Chile (1846,1852); Espanha: Modesto Lafuente, Historia General de España, desde los tiempos más remotos hasta nuestros días (1850); México: Lucas Alamán, Historia de México desde los primeros movimientos que prepararon su independencia en el año de 1808 hasta la época presente (1849-1852); Peru: José Manuel Valdez y Palacios, Bosquejo sobre el estado político, moral y literario del Perú en sus tres grandes épocas, 1844; Portugal: Alexandre Herculano, História de Portugal desde o começo da monarquia até ao fim do reinado de Afonso III (1846-1853); Venezuela: Feliciano Montenegro y Colón, Historia de Venezuela (1837) e Rafael María Baralt, Resumen de la Historia de Venezuela (1841). A esse respeito, a Argentina parece ser a exceção à regra. Durante o período não há uma história semeIhante, se bem que o caminho está cheio de reflexões para estabelecer o programa de uma história nacional futura.

Dentro de uma perspectiva de longa duração, fica a questão acerca de se estas histórias nacionais constituem autênticos "pontos de partida" ou poderiam ser vistas como o fim de um período. De imediato, trata-se em geral de histórias modeladas sob um espírito mais liberal que providencialista. No entanto, estas histórias não descartam a presença de enfoques providencialistas. Não se trata de uma contradição, só revela-se a separação tradicional entre uma história escrita por Deus, perfeita e completa por natureza, e uma história humana incompleta e aberta à ação livre do homem. 0 sentido universalista da nova história inclui em seu repertório todo tipo de histórias; mas sujeitas agora a uma nova ordem de historicidade, como se registra em um testemunho de Juan Donoso Cortés, de 1838: "Se o gênero humano, enfim, tem uma história da qual as histórias particulares são fragmentos, as revoluções que nela se consignam, as catástrofes que nela se descrevem e o movimento progressivo que nela se percebe, são obra da casualidade ou efeitos necessários produzidos por princípios necessários também e por leis providenciais e eternas?".64 
65

LISTA, Alberto (1830). Sobre el estudio de la historia de España. Gaceta de Bayona, no 141, 5 fevereiro.

66

Ainda que seja previsivel que o religioso (a experiência religiosa) também seja afetado.
0 conceito de uma história intrínseca ao próprio devir histórico é articulado também por Alberto Lista em 1830: "A este importante estudo [da história] estão ligados o dos diferentes caracteres e espíritos das nações, seus recursos em população e riqueza, sua educação religiosa e civil, seus jogos, seus espetáculos, suas ciências e artes, seus vícios e virtudes, seus erros e preocupações; enfim, tudo o que pertence à humanidade (...) Se o estudo deste ramo interessante de conhecimentos é necessário ao filósofo racional, ao moralista, ao político, ao guerreiro e ao literato, muito mais será o da história pátria, que é o que mais Ihe importa conhecer: porque se é verdade que a idade presente está prenhe da futura, também o será que, nos acontecimentos passados, está a origem da atual situação das nações, na qual pode o homem reflexivo prognosticar até certo ponto qual será seu destino; e não importa fazer esta espécie de horóscopo de nenhum povo tanto como do seu próprio".65

\section{A história como filosofia da história}

Como se nota, a centralidade da história durante este período se projeta em um conceito filosófico da história. Não obstante, convém distinguir esta noção de "histórias filosóficas" dos philosophes franceses. 0 novo sintagma passa a ser parte do vocabulário sócio-político a partir da década de 1830. A história deixa de ser uma mera narração de acontecimentos e se transforma em um conjunto de novas experiências e categorias explicativas. É significativa, por exemplo, a evolução em relação à distinção entre historiógrafo (antiquário) e historiador moderno. Enquanto o historiógrafo relata acontecimentos, reúne materiais, o historiador seleciona, ordena, examina os fatos, julga os homens e suas coisas. 0 historiador costuma ser menos adulador e mais imparcial que o historiógrafo. Um dicionário de 1850-53 acabou por estabilizar no Brasil o novo conceito de história entendido como um singular coletivo.

Parece haver uma coincidência em quase todos os trabalhos: o político e o social, mais que as linguagens puras, são deflagradores da necessidade de buscar novas fórmulas para descrever as novas situações. 0 surgimento do novo conceito de história na Alemanha na busca da origem de si mesma, por outro lado, se relaciona também com uma reação germânica à influencia latina (Herder). A Historie latina tenderá a ser substituída pelo vocábulo alemão Geschieht. Não parece encontrar-se uma reação similar no contexto ibero-americano. Inclusive o abandono do latim como língua franca a favor das línguas vernáculas passa de modo indefectivel pelo filtro ou pela marca impressa do latim.

Nesse sentido se postularia que o aparecimento de uma nova noção de História, como a do neologismo Opinião Pública, se apresenta como uma forma de enfrentar e resolver os novos problemas do exercicio e representação da autoridade pública. No caso da Opinião Pública, esta surge como substituto do Soberano ausente ou Cabeça do organismo social. No caso da História, esta se apresenta como uma forma de responder a um futuro incerto, quer dizer, um futuro que deixou de se pautar no social e no politico - mas não no religioso - pelo passado. ${ }^{66}$ Trata-se de um lapso em que o passado tornou-se questionável e, portanto, deixou de ser modelo de imitação. Mais especificamente, o novo conceito de história surge como reação contra a história humanista plasmada durante o Renascimento, por um lado, e como uma reação historicista ante as verdades da história sagrada, por outro. 
HAZARD, Paul. La crisis de la conciencia europea 1680-1715. Madrid: 1988.
Dentro deste processo aparece a crescente importância que vieram ganhando as ciências experimentais ou da natureza, ${ }_{1}^{67}$ que implica na perda do halo mágico ou sagrado que a natureza ainda possuía como obra criadora de Deus. A história natural, base da física, cumprirá a esse respeito um papel primordial entendida como a capacidade para contemplar a natureza regulada por princípios objetivos. Esta aptidão desenvolvida inicialmente entre os naturalistas será logo trasladada para o âmbito da natureza humana, uma natureza não inata e imutável, mas sim perfectível. Esta transposição do âmbito natural ao cultural abre a possibilidade da formação de uma história sem mais ou "história geral", cujo fundamento deixa de ser externo ao próprio devir. A história aparece então como um processo regulado por si mesmo e, portanto, capaz de compreender-se a partir de si mesma.

Segundo Koselleck, tal fenômeno deu-se na Alemanha como resultado de um processo de reflexão interna entre os letrados, assim como de maneira paralela pode haver se apresentado na França da llustração. Por outro lado, no caso ibero-americano, pareceria que a suspeita de um novo uso da palavra história não é produto de um processo imanente, mas apresenta-se como um cheque em branco relacionado com o pais que se aspira ser; não é tanto o resultado de uma experiência, mas projeta-se como a abertura de novas possibilidades.

Poderia parecer que na descrição oferecida por Koselleck há uma espécie de relato teleológico: o caso alemão prefigura no âmbito lingüístico o que ocorreria depois no caso dos fatos políticos e sociais. A autocoroação de Napoleão poderia simbolizar o estabelecimento desse ponto zero ou nascimento da nova forma de historicidade, uma forma que já não precisa do passado dinástico e canônico para existir, para obter sua legitimidade e aprovação. Mas esse início que marca um ponto de ruptura radical com as formas do passado acarreta, por sua vez, um paradoxo: de que maneira se explica essa devoção e fascinação pelo passado que emergirá e se projetará de muitas maneiras no futuro desse passado, nossa modernidade? Assim, a emergência de um novo conceito de história se realiza no contexto de uma grande ambivalência: auto-suficiência em relação ao presente e ao mesmo tempo devedora e necessitada desse passado para dar ao presente o apoio do qual carece. 0 problema é que se trata, em principio, de um passado já esvaziado de seu conteúdo moralizador tradicional.

Em termos gerais, o caso espanhol mostra várias coincidências com o brasileiro quanto à evolução do termo. Na Espanha não se encontra a história filosófica que caracterizaria o novo uso do termo, a não ser até as obras de autores como Donoso Cortés e Alberto Lista, ou seja, entre 1830 e 1850, aproximadamente. No caso argentino, é somente com Sarmiento (1851), Mitre (1857) e Vicente Fidel López (1845) que se perfila o uso filosófico da história. No México, a obra de José Maria Luis Mora, México y sus revoluciones (1836) é representativa desta tendência. 0 mesmo no Chile, onde as reflexões de Andrés Bello são ilustrativas da presença da inflexão filosófica na história: "...só pelos fatos de um povo individualizados, vivos, completos, podemos chegar à filosofia da história desse povo...".

Pareceria que a coexistência de uma linha clássica e outra moderna tende a perder-se no momento em que se desenvolve um discurso filosófico da história; ou seja, quando a história emerge no horizonte como um problema. É evidente que se os atores não experimentam a história como ruptura, se privilegiará a idéia de uma continuidade entre passado 
68

Grifo do autor. Em Fabio Wasserman "Historia". e presente, condição para que o discurso histórico cumpra uma função magisterial e pedagógica. Ao mesmo tempo, no contexto do processo de independência se mostra o surgimento e predominância da história contemporânea na qual, no entanto, continuam assumindo-se valores próprios da história do antigo regime. Só implicitamente se reconhece que a história cumpre sobretudo uma função política, mais que cognitiva.

Talvez Facundo. Civilización y barbarie (1845), de Domingo Sarmiento, seja um caso paradigmático da transformação ocorrida na semântica da história. Evidentemente Sarmiento é representativo de uma noção tal como a descrita por Koselleck para a Alemanha. Ao ser nomeado Diretor de História do Ateneo del Plata, Sarmiento declara em 1858: "(...) não chegamos a épocas definitivas em que as sociedades tenham tomado parte, como o viajante que descansando já debaixo do teto hospitaleiro, dirige retrospectivos olhares para o caminho que andou. Nós escrevemos a história caminhando".68 Esta declaração descreve de maneira contundente a nova experiência da temporalidade. A história, orientada em princípio diacronicamente, acabou por sincronizar-se com o espaço onde é escrita. 0 texto de Vicente Fidel López (1845) revela igualmente o desenvolvimento de uma nova sensibilidade em relação à história: "(...) a história é a representação científica e literária de todos os fatos que modificam o modo de ser das nações...". "(...) Nesta ciência está envolvida nada menos que a revelação da natureza do homem e da sociedade (...) Na época em que vivemos, temos todos uma necessidade indispensável de estudos históricos. Todos somos cidadãos capazes de obter um posto eminente na direção dos Estados, e não há nada mais necessário, para dirigi-los bem, que conhecer sua natureza, para não violentá-la nem permitir extravios perigosos. Assim, pois, o estabelecimento do Governo Representativo fez que a história que antes não era mais que a ciência dos príncipes seja hoje a ciência dos cidadãos [...]".

\section{Para concluir}

Neste ensaio, finalmente, se procurou ressaltar mais as coincidências que as diferenças mostradas nos nove casos examinados. Recorreu-se à hipótese desenvolvida por Koselleck para iluminar o trajeto alemão em direção à história moderna, e encontrou-se que o caso ibero-americano não está muito distante do mesmo traço, ainda que os fatores, sua combinação e seu peso específico possam diferir em cada um dos casos estudados. Portanto, o que se tratou de desenhar aqui é uma hipótese geral para continuar investigando e pontuando as particularidades de cada um dos processos. Por isso ainda é prematuro tentar lançar conclusões definitivas.

Em geral, se propõe que as coincidências existentes se devem, em boa parte, ao fato de compartilharem referências intelectuais e políticas afins. Para isso a imprensa e sua inserção em alguns lugares no momento das revoluções ocupou um papel central. Dessa forma se favorece a circulação de textos impressos e a informação que permite que o mesmo possa ser lido simultaneamente em diversos lugares. Haveria que detalhar ainda mais a recepção ou as formas de adaptação e tradução de obras estrangeiras que se realizam em cada situação. Haveria que examinar também como as mesmas denominações podem adquirir valorações distintas, segundo circulem em língua espanhola ou portuguesa.

Foi possivel apreciar que a formação do espaço de experiência conhecido como "moderno" em sentido estrito começa a ser gerado aproxima- 
damente em 1808 e se manifesta no aparecimento de novos sintagmas relacionados com a palavra história, tais como, "história contemporânea" e "filosofia da história". Isto ocorre em quase todos os casos até depois de 1820, de modo mais claro entre 1830 e 1850 . Assim, se pode postular que a transformação semântica da história na América Ibérica passa pela redefinição dos projetos imperiais espanhol e português. É com as independências que se inicia um processo de re-elaboração conceitual da herança imperial no seio do vocabulário político e social. Na medida em que o futuro esperado não se manifeste, a experiência moderna da história irá assumindo o perfil de uma permanente transição. Como uma forma de compensar a instabilidade, serão tecidas histórias gerais que expliquem as origens da nação assim como permitam vislumbrar o futuro esperado. Os relatos históricos adquirirão nesse sentido, um caráter filosófico. As diferentes formas que adquiram dependerão do lugar que se ocupe ou se ocupou no trajeto, como parte de um império ou, caso contrário, como uma ex-colônia.

Recebido para publicação em

fevereiro de 2008 


\section{Historia, experiencia y modernidad en iberoamerica, 1750-1850'}

\section{Guillermo Zermeño Padilla}

Centro de Estudios Historicos, El Colegio de México

\section{Resumen}

Basados en la propuesta de Reinhart Koselleck se examinan nueve casos iberoamericanos para comprobar si en esta región hubo o no la experiencia de la historia conocida como "moderna". Esta nueva experiencia se distinguiria por desarticular y reconfigurar las relaciones clásicas de temporalidad. Nuestra hipótesis a partir de los resultados obtenidos tiene una respuesta afirmativa. Si bien, se pueden advertir traslapes y un desarrollo no necesariamente uniforme. En especial, esto se sugiere al poner en juego y comparar las experiencias históricas de los antiguos centros imperiales (Madrid y Lisboa) y las antiguas colonias (Argentina, Brasil. Chile, Colombia, Perú, México, Venezuela).
Extiendo de manera más puntual mi agradecimiento a Sergio Campos Matos, Javier Fernández Sebastián, Valdei Lopes de Araujo, Joao Paulo Pimenta, Peer Schmidt y Victor Samuel Rivera, quienes me permitieron mejorar versiones previas con sus comentarios y sugerencias criticas. 
2

Los resultados de estos estudios se publicarán próximamente en el Diccionario Politico y Social Iberoamericano. Conceptos politicos en la era de las independencias, 1750-1850, Madrid, Centro de Estudios Políticos y Constitucionales.

Por ejemplo, un historiador mexicano hacia 1950 escribe: "Creemos que en la Reforma está la clave de la Modernidad; en la cual -digamos aunque de pasada- aun nos encontramos los pueblos hispánicos, no por casualidad ni por cortedad de luces, un poco como a regañadientes o como huéspedes a veces extraños y, las más, morosos. No será, pues, ocioso añadir que en la Reforma está la llave de la Antimodernidad hispánica". ORTEGA Y MEDINA, Juan. Reforma y modernidad. México: Alicia Mayer González ed., 1999. p. 23. Para un examen de las paradojas inscritas en la "modernidad moderna" véase, LUHMANN, Niklas. Lo moderno de la sociedad moderna: complejidad y modernidad, de la unidad a la diferencia. Madrid: Trotta, 1998. p.131-153.

SEBASTIÁN, Javier Fernández. "Modernidad". IN SEBASTIÁN, Javier Fernández y FUENTES, Juan Francisco (orgs.). Diccionario politico y social del siglo XIX español. Madrid: Alianza Editorial, 2002. p.453-462. KOSELLECK, Reinhart. Vergangene Zukunft. Zur Semantik geschichtlicher Zeiten. Frankfurt: 1979. p.302; Versión en español: Futuro Pasado. Para una semántica de los tiempos históricos. Barcelona: 1993. p.289. En el término "modernidad" (Modernität) se sintetiza cualquier evento relacionado con lo reciente, lo actual, lo moderno. La aparición del concepto señala la condensación de una experiencia compleja, multifactorial.
En este ensayo se intenta realizar una sintesis comparativa de la evolución del término historia y su relación con la formación de un nuevo espacio de experiencia caracterizado como "moderno". Es un ejercicio hecho desde nuestro ámbito lingüistico y cultural enmarcado y enriquecido por las contribuciones del historiador alemán Reinhart Koselleck. El análisis se basa fundamentalmente en las aportaciones hechas sobre nueve paises: Fabio Wasserman (Argentina), Valdei Lopes de Araújo/ Joao Paulo Pimenta (Brasil), Jorge Orlando Melo (Colombia), Aldo Yávar Meza (Chile), Pedro José Chacón Delgado (España), Guillermo Zermeño (México), Victor Samuel Rivera (Perú), Sérgio Campos Matos (Portugal) y Ángel Rafael Almarza Villalobos (Venezuela). ${ }^{2}$ Salvando la responsabilidad propia de quien esto escribe, considero que en esencia se trata de un ensayo colectivo. Las contribuciones mencionadas nos permiten a todos mirar más allá de nuestras fronteras culturales, lo cual no es poca cosa.

En esta ocasión, primeramente me voy a permitir presentar una sintesis de la propuesta o hipótesis general desarrollada por Koselleck. Sus textos son del dominio público, y la mayoría de ellos al alcance en nuestra lengua desde hace algunos años. Así, mi acercamiento sólo tiene la función de circunscribir los márgenes sobre la cual se intentaria dilucidar el ingreso del mundo iberoamericano en la modernidad. Se trata de un ámbito cultural plagado de equívocos, en general rodeado todavía de una cierta "leyenda negra" que, paradójicamente, tiene vigencia al mismo tiempo en que se van dando las condiciones para la formación un nuevo tipo de experiencia histórica o de temporalidad descrita como "moderna".

Establecido el marco conceptual característico de los conceptos "modernos" de historia y modernidad, es posible pensar y plantear los márgenes en los que es legitimo abrir el compás para la comparabilidad entre diversos tipos de experiencias de la historia sostenidas en lenguajes y culturas limitrofes. Como se dijo, para el ámbito alemán el trabajo de dilucidación ha sido realizado entre otros por Koselleck, una labor que en nuestro ámbito es posible iniciarlo contando con la colaboración de quienes forman parte activa de este proyecto. Por eso estas líneas tienen el propósito principal de iniciar un trayecto de investigación más que señalar el punto de llegada; se trata sólo de indicar un punto de arranque para seguir avanzando en este tipo de investigaciones, en particular, sobre el concepto de historia.

\section{PREÁMBULO METODOLÓGICO}

\section{La modernidad como concepto histórico}

Como se anuncia en el título, a lo largo del escrito se pone especial énfasis en tres conceptos aledaños: historia, experiencia y modernidad. La mención de esta última noción contiene particularmente una carga polémica por lo cual se exige desde el inicio su clarificación. 3 "Modernidad" es un término actualmente en boga, de uso corriente que sirve básicamente para referirse a lo más actual, lo más nuevo. Su uso más o menos constante muestra que se trata de un término que sirve para describir la dinámica de las sociedades contemporáneas. Pero su aparición como un sustantivo genérico es relativamente reciente como se advierte en el Diccionario politico y social del siglo XIX español. En lengua castellana quizás sea el filósofo José Ortega y Gasset quien lo consagra a partir de la década de 1910. En cambio en lengua alemana su aparición se registra a partir de $1870 .{ }^{4}$ 
Desde la sociología de sistemas Niklas Luhmann es uno de los autores que con mayor radicalidad plantea los problemas no sólo históricos, sino ante todo lógicos, para describir lo que sucede al interior de esta "modernidad moderna" y sus consecuencias. Véase al respecto LUHMANN, Niklas. Lo moderno de la sociedad moderna: complejidad y modernidad, de la unidad a la diferencia. Madrid: Trotta, 1998. p.131-153.

6

Al respecto es de interés el libro de LOMNITZ, Claudio. Modernidad Indiana. Nueve ensayos sobre nación y mediación en México. México, 1999. p.9-12. Si bien en una primera instancia recupera la dimensión cualitativa de la noción de modernidad (Weber y Habermas), sin embargo no logra desprenderse del esquema que sitúa su origen en el siglo XVI, con la consecuencia de que México aparece a veces moderno y otras veces antimoderno. En esta versión parece todavía dominar una concepción instrumental de la modernidad aparejada con "modernización". Al final el término modernidad aparece como una noción ideológica, y no tanto como una experiencia de temporalidad.

\section{7}

KOSELLECK, Reinhart. Vergangene Zukunft. Zur Semantik geschichtlicher Zeiten. Frankfurt: 1979. p.310, (Versión española, p.296-7). Además, GRUMBRECHT, Hans Ulrich. A History of the Concept "Modern": Making Sense in Life and Literature. Minneapolis: 1992. p.79-110; OSBORNE, Peter. Modernity is a Qualitative, Not a Chronological Category. New Left Review, London, 192, p.65-84.

En una historiografia acumulativa dominada por la cronologia la periodización no remite a las novedades del tiempo en el que se encuentran los historiadores, sino a los nuevos datos proporcionados por el pasado.

9

KOSELLECK, Reinhart. Op.Cit., p.311; (Version española p.297-8).

10

Ibidem, p.315; (version española p.301).
Frente a una noción de "modernidad" fundada en una historia de las ideas y que remite su origen a las guerras de religión del siglo XVI aquí se contrapone una noción de modernidad fundada en una historia de los conceptos. De acuerdo con el primer enfoque prevalece una línea de continuidad entre las experiencia del siglo XVI y las del XX. Por el contrario, la Begriffsgechichte permite mostrar precisamente las discontinuidades a través del análisis del lenguaje o de los actos de habla. Desde esta perspectiva sería así impropio hablar de orígenes de la modernidad en el siglo $\mathrm{XVI}$ al no encontrar en el vocabulario de la época el uso de la palabra "modernidad", tal como será desarrollado a partir del siglo XIX. Una noción "moderna" de lo moderno alimentada y proseguida retrospectivamente por historiadores, filósofos o antropólogos "modernos". Desde la situación de la historiografía actual se trata de una elaboración intelectual que impide distinguir los rasgos propios de la cultura que domina y marca a quienes habitaron el mundo a parir del siglo XVI. ${ }^{5}$ Es desde esa modernidad implantada de lleno en el lenguaje del siglo XX que Ortega y Medina (cita 2) realizó su ejercicio retrospectivo para intentar describir las anomalias del proceso iberoamericano con respecto al de las culturas del norte de Europa.

Aqui se sostendría que los orígenes de la modernidad se remontan al lapso que va de fines del siglo XVIII al siglo XIX, y que los indicios de esta mutación semántica se localizan en el vocabulario de sus contemporáneos. La hipótesis seria la siguiente.

a) La noción de modernidad se relaciona estrechamente con la de experiencia ya que se trata de una categoria histórico cualitativa y no meramente cronológica. ${ }^{6}$ Este rasgo distintivo consiste en que el término ya no designa solamente a lo nuevo, sino que se presenta como una experiencia inédita que no encuentra semejanzas con otras anteriores. Por esa razón el pasado comienza a deja de tener funciones normativas en el presente. Así, la aparición de un tiempo específicamente moderno implica la creación de un nuevo espacio de experiencia fundado menos en la emulación del pasado y mucho más en futuros proyectados. Esta discordancia entre el pasado conocido y el futuro deseado genera un discurso histórico que paradójicamente lo aleja progresivamente de las épocas pretéritas. ${ }^{7}$

b) El rasgo distintivo de esta modernidad entonces es su relación con la temporalidad. En la vida cotidiana el tiempo fluye como un continuum para todos. El mañana es transformado por el hoy en un ayer. En la historiografía premoderna, por ejemplo, se registran y fijan por escrito los sucesos cronológica y acumulativamente. El presente existe sólo como el límite de los sucesos narrados. De acuerdo con presentes ulteriores se irán añadiendo y completando las relaciones. Sin adentrarse en el análisis de la retórica de los textos estos relatos históricos transmiten la impresión de un presente continuo enriquecido con los hechos del pasado que se amplia y extiende de manera progresiva. ${ }^{8}$ También dejan ver la formación de un espacio de experiencia más 0 menos homogéneo y constante. Por esa razón a lo más reciente no se le otorga un peso específico, bien porque las historias se repiten en su estructura o porque antes del fin del mundo no es esperable que suceda algo completamente distinto. ${ }^{9}$ Para que esto suceda, siguiendo a Koselleck, hace falta que la expectativa cristiana del juicio final pierda "su carácter de presente continuo".10 Y esta reflexión, incluso, 
11

KOSELLECK, Reinhart. Vergangene Zukunft. Zur Semantik geschichtlicher Zeiten. Frankfurt: 1979. p.318-21; ( version española p.305-7). Koselleck utiliza en alemán la expresión neueste Geschichte y no gegenwärtige Geschichte que presupone la neue Geschichte o historia más reciente sinónimo de moderna. De tal modo que además de la noción moderna que diferencia a la época de la antigua y medieval, se introduce otra más: la "más nueva" o más reciente, que Ranke sitúa a partir de la revolución americana y francesa. El sufijo -ste deja ver que se deja atrás el comparativo -ere, para designar que se trata de una historia acabada, propia, diferente, que no se asemeja a otra. La diferencia entre el neue Zeit y el neueste Zeit señalaría entonces el momento en el que la "modernidad" comienza a sostenerse sobre sí misma.

\section{2}

Ibidem, p.317-8; (version española p.303-4). Una expresión historiográfica de esta "modernidad" propia de la segunda mitad del siglo XVIII es el trabajo de RANKE, Leopold Von. Pueblos y Estados en la historia moderna. (tr. Wenceslao Roces). México, FCE, 1979 (1ª ed. en español de 1948). Se trata de una compilación de trabajos de Ranke publicados en Alemania en 1945, de tal modo que el título probablemente no sea autoría del propio Ranke. Solamente el capitulo dedicado a la "Epocas en la Historia" si está tomado de una obra editada en 1888 , un periodo en el que el concepto de modernidad ya estaba diseminado, con el título "Sobre las épocas de la historia más reciente o moderna" (Über die Epochen der neueren Geschichte). Es el esquema propuesto por obras como las de Ranke en el que se inspira el trabajo mencionado arriba de Ortega y Medina para pensar el complejo ingreso de los paises iberoamericanos en la modernidad.

\section{3}

SEBASTIÁN, Javier Fernández. "Modernidad". IN SEBASTIÁN, Javier Fernández y FUENTES, Juan Francisco (orgs.). Diccionario politico y social del siglo XIX español. Madrid: Alianza Editorial, 2002. p.453-462.

\section{4}

La explicación de ello radica en el hecho en que toda época es ciega al momento de observar. La época experimenta la vivencia de la aceleración del tiempo, pero no consigue ver la aceleración misma.

15

Kant ya habia observado que la cronología debía establecerse de acuerdo con la historia, y no ésta según el desarrollo de la cronología. Este giro presupone la separación de una cronología vinculada al ciclo de la naturaleza y al de la sucesión de las dinastías reinantes. Preparado por Vico, añade Koselleck, estaba naciendo un tiempo especificamente "histórico". KOSELLECK, Reinhart. Futuro Pasado. Para una semántica de los tiempos históricos. Barcelona: 1993. p.308 no está desarrollada enteramente durante el llamado siglo de la llustración. En el estudio de Koselleck ésta comienza a presentarse solamente hasta después de 1789. Un sentido del tiempo como aceleración independizado del esquema escatológico cristiano comienza a cobrar relevancia solamente a partir del primer decenio de 1800, asociado a la resemantización de antiguas palabras como "revolución", "progreso", "desarrollo", "crisis", "espíritu del tiempo", todas ellas que traducian la nueva experiencia del tiempo en términos de movimiento. ${ }^{11}$

Es de notar además que la modernidad -en tanto que noción no cronológica sino cualitativa o de experiencia alimentada por las expectativas de futuro- no es constitutiva todavía de la discusión historiográfica del siglo XVIII. Sí lo es, en cambio, la integración de un concepto de modernidad que permite diferenciar la propia época de otra como la Edad Media cuya duración no va más allá de tres siglos. ${ }^{12}$ Colofón de este proceso es la aparición de la noción de historia contemporánea al interior de la historia moderna hacia 1775 , indicando con ello un cambio en la percepción del tiempo como aceleración.

c) Asimismo se puede ver la evolución del concepto "moderno" ligado al de "historia". Su trayectoria va de las Historien o crónicas tradicionales asociadas a un espacio de experiencia que permanece fundamentalmente idéntico consigo mismo; pasa luego al de "historia" entendida como un proceso autónomo hasta desembocar en un tiempo caracterizado como moderno sin más, que depende cada vez menos del pasado y más del futuro.

d) Se trata de una experiencia global que atraviesa tanto a paises metropolitanos como a las provincias imperiales. La resemantización del vocablo historia, al lado de otros conceptos vecinos como progreso y cultura, sería uno de los indicios de la creación de un nuevo espacio de experiencia que imprime su sello a esta época. ${ }^{13}$

e) Derivado de lo anterior, la forma como hasta la década de 1950 se concebía a la modernidad no hace sino proseguir un esquema de periodización fabricado durante la segunda mitad del siglo XVIII, en el cual se enfatiza su carácter cronológico, dejando fuera su carácter cualitativo relacionado con la noción de experiencia temporal. ${ }^{14}$ Sin este aspecto, en la hipótesis crítica que nos propone Koselleck, la modernidad no acaba de comprender lo que implica ser parte de la modernidad. Pero, como se sugirió, una nueva caracterización de la modernidad sólo es posible si a la cronología se le adjunta su carácter cualitativo. ${ }^{15}$ Así, ésta se debe menos a fenómenos puramente externos, y más a la manera cómo éstos van siendo procesados. En ese sentido, más que a la historia económica, la comprensión de la modernidad como experiencia temporal pertenece al espacio de la historia intelectual y cultural. Se relaciona con el proceso de interiorización de un nuevo tipo de experiencia no reducible a individuos aislados, sino a la sociedad en conjunto. Una de las caracteristicas de esta modernidad a diferencia de la modernidad humanista o renacentista consiste, precisamente, en sincronizar lo que hasta entonces parecia que no tenía que ver una cosa con la otra. En ello radica la fuerza del nuevo vocabulario social y político propio de esta modernidad: su conversión en conceptos singulares y universales a la vez. 
16

KOSELLECK, Reinhart. Vergangene Zukunft. Zur Semantik geschichtlicher Zeiten. Frankfurt: 1979. p.349; Versión en español: Futuro Pasado. Para una semántica de los tiempos históricos. Barcelona: 1993. p.333.

17

KOSELLECK, Reinhart; GADAMER, Hans-Georg. Historia y Hermenéutica. Barcelona: 1997. p.117.

18

Ibidem, p.118

\section{9}

Francois Hartog da un paso adelante al proponernos la noción "régimen de historicidad" como una herramienta heurística "que contribuya a aprehender mejor no al tiempo, ni todos los tiempos, ni el todo del tiempo sino, principalmente, momentos de crisis del tiempo, aqui y allá, justo cuando las articulaciones entre el pasado, el presente y el futuro dejan de parecer obvias"; HARTOG, François. Órdenes del tiempo, regimenes de historicidad. Historia y Grafia, México, 21, 2003. p.98. Aquí lo relevante es el énfasis dado al hecho de detectar los "momentos de crisis del tiempo", como el que domina en la actualidad. En el diagnóstico de Hartog después de pasar revista a tres regimenes de historicidad (heroico, clásico y moderno) se estaría en medio de la crisis del régimen moderno de historicidad, foco de atención de nuestros análisis. Véase su libro HARTOG, François. Régimes d'historicité. Présentisme et expériences du temps. Paris: 2003.

\section{Lenguaje e historia}

Una premisa metodológica central de la Begriffsgeschichte es postulada por Koselleck al inicio de uno de sus ensayos. Sintetiza su programa en una frase tomada de Friedrich Schlegel cuando éste reflexionaba acerca de ¿qué era, cómo se conocía y cómo se debía escribir la historia?: "No se puede decir que algo es, sin decir lo que es". Esto es, no hay mundo sin lenguaje. "Al pensar los hechos, estos ya de suyo se refieren a conceptos". Y esto no es una cuestión indiferente: sin conceptos no hay mundo. ${ }^{16}$

Los nexos entre decir y hacer cobran especial relevancia en este proyecto historiográfico, puesto que no hay mundo sin lenguaje, ni lenguaje sin mundo. Por ejemplo, en las lenguas germánicas e indogermánicas, en la raíz del término mundo (Welt, World) ya está metido el hombre (Wer), explica Gadamer. "Mundo" es mundo humano, del hombre. ${ }^{17}$ Por consiguiente, el mundo no es un objeto dado de antemano (tal es la crítica de Kant a toda clase de metafísica dogmática), y en consecuencia no puede ser explicado como un todo utilizando las categorías de la ciencia experimental. Más bien, afirma Gadamer, el mundo existe como horizonte de posibilidades, abierto, al tiempo que se busca acotarlo y ganar orientación. Esto es realizado por medio del lenguaje y de la comunicación. La posición del hombre, intermedia entre un ser vivo de la especie animal y humana, lo sitúa por encima de las líneas del instinto natural de sobrevivencia. ${ }^{18}$ Lo hace ver fundamentalmente como un ser hablante. Gadamer denomina a esta esfera "lingüisticidad", como específica del ser humano, no reducible exclusivamente al mundo de los textos, la cual de acuerdo con Aristóteles establecería la pauta principal para diferenciar la condición del ser humano de otros seres vivos.

Por tanto, además de las categorías históricas para discernir el carácter y sentido de la acción social y política, se requiere un tipo de categorias suprahistóricas como el de la "lingüisticidad", ya que los conceptos propios del historiador son insuficientes para establecer las diferencias con las sociedades animales. En estas se encuentran también las relaciones de poder cifradas en antagonismos tales como, arriba/abajo, supremacia/sumisión, dentro/fuera, inclusión/exclusión. Siguiendo a Gadamer, el estudio de las sociedades animales (etología) sería muy útil para enseñarnos acerca de las grandes similitudes existentes entre el reino animal y el humano; pero al mismo tiempo para dejar ver las diferencias. $Y$ estas se realizan no de manera natural, sino en el ámbito del lenguaje.

Corolario de esta premisa es que sólo por medio de la observación y el análisis del lenguaje es posible acceder al espacio de experiencia propio de cada época. Permite observar la manera como las sociedades procesan sus relaciones con la temporalidad. De esa manera la modernidad entendida como una forma particular de experiencia sólo es tematizable a partir de la observación de la evolución de las palabras y su transformación semántica. Koselleck sitúa esta transformación del sentido de temporalidad durante el lapso de 1750-1850.19

En ese sentido, la Begriffsgeschichte proporciona una de las formas posibles para adentrarse en la historia a través de la evolución y transformación del significado de las palabras. Situar esta exploración en el marco de la modernidad implica, por tanto, intentar observar el momento y el contexto en el que se fue gestando un nuevo vocabulario apropiado a esa experiencia, dejando ver asimismo un nuevo posicionamiento respecto del 
20

KOSELLECK, Reinhart. Vergangene Zukunft. Zur Semantik geschichtlicher Zeiten. Frankfurt: 1979. p.349-375; KOSELLECK, Reinhart. Futuro Pasado. Para una semántica de los tiempos históricos. Barcelona: 1993. p.333-357.

21

Así, Tocqueville cuando visitó a los Estados Unidos pudo constatar no que la cultura observada era superior a otras, sino que ésta era "diferente" a lo observado históricamente. TOCQUEVILLE, Alexis de. La democracia en América. México: 1957. p.643-644.

22

KOSELLECK, Reinhart. Op.Cit, p.338. mundo y sus posibilidades. Ese es el marco general en el cual se desarrolla la principal hipótesis que orienta esta investigación.

Si se ha desechado la opción de comprender a la modernidad como un proceso continuo que abarca cinco siglos se debe a que no ha sido capaz de orientarnos en torno al sentido de temporalidad que la constituye. Su rechazo no significa que no sea posible reconocer elementos técnicos que juegan un papel fundamental en la composición de ese nuevo espacio de experiencia. Pero más que como elementos ordenados secuencialmente en términos causales, la manera como se agrupan establece una diferencia o separación con el momento en que aparecieron. Por el contrario, si se parte de la periodización propuesta por Koselleck (1750-1850) para identificar el cambio o mutación del sentido del tiempo (un nuevo régimen de historicidad en términos de Hartog) entonces se exige mostrar las relaciones que puede haber entre historia y experiencia.

\section{Historia y experiencia}

Koselleck se enfocó a dilucidar y esclarecer la transformación semántica de la palabra historia durante este periodo como indicio de la formación de un nuevo espacio de experiencia. En su indagación es inseparable la observación del uso del lenguaje de los contemporáneos (el lenguaje del pasado) y el uso de un lenguaje propio del historiador (el lenguaje del presente). Pues es evidente que la palabra historia y sus variantes se encuentran en los textos del pasado, pero no así nociones tales como "espacio de experiencia" y "horizonte de expectativas". 20 Estas categorias postuladas a priori-antes de toda experiencia- son las que permitirian establecer los nexos posibles que hay entre lenguaje y experiencia, y a la vez, las que abren la posibilidad de comparación entre diversos tipos de experiencias históricas.

En la hipótesis de Koselleck existe una relación estrecha entre la aparición del neologismo Geschichte (historia como acontecer) -que paulatinamente se va imponiendo al concepto tradicional Historie (historia como relato) - y la formación de un nuevo espacio de experiencia con su respectivo "horizonte de expectativa". Ambas expresiones han sido derivadas de las categorías kantianas del conocer (espacio y tiempo). Y la cuestión metodológica central consistiria en aprender a distinguir las diversas formas de coordinación que pueden darse entre experiencia y expectativa, entre pasado y futuro. Con este procedimiento heuristico compartido lo más seguro es que se constatarian la diversidad de experiencias que pueden darse dentro de lo mismo. ${ }^{21}$ La condición inicial de esta clase de observación consiste en reconocer la dimensión temporal de toda existencia humana. Así para Koselleck la experiencia "es un pasado presente (gegenwärtige Vergangenheit), cuyos acontecimientos han sido incorporados (einverleibt) y pueden ser recordados (erinnert). En la experiencia se fusionan tanto la elaboración racional como los modos inconscientes del comportamiento que no deben, o no debieran ya, estar presentes en el saber".22

Es evidente que al momento de llegar Europa a América se encontró con otra cultura, que ese mundo no era como Europa. Esta percepción está vigente en el siglo XVIII, incluso se ha profundizado, cuando el arzobispo de México Francisco Lorenzana en 1770 declara que "Dos Mundos ha puesto Dios (Providencia) en las Manos de Nuestro Católico Monarca, y el Nuevo no se parece al Viejo, ni en el Clima, ni en las costumbres, ni en los naturales; tiene otro Cuerpo de Leyes, otro Consejo para gobernarle, mas 
23

LORENZANA, Francisco Antonio. Historia de Nueva-España, escrita por su esclarecido conquistador Hernán Cortés, aumentada con otros documentos, y notas, por ...Arzobispo de México. México: Imprenta de Joseph Antonio de Hogal, 1770. (Edición facsimilar: México, Porrúa/SHCP: 1981. p.4-6).

24

LUHMANN, Niklas. Lo moderno de la sociedad moderna: complejidad y modernidad, de la unidad a la diferencia. Madrid: Trotta, 1998. p.133.

25

KOSELLECK, Reinhart. Historia/historia.

Barcelona: Trotta, 2004.

26

Entre otros testimonios Koselleck evoca el de un amigo de Goethe al escribirle en 1820: "Tiene usted toda la razón, mi estimado amigo, en lo que dice sobre la experiencia. Para los individuos siempre llega demasiado tarde, para los gobiernos y los pueblos (la experiencia) no está nunca disponible. Sucede así porque la experiencia ya hecha se expone unificada en un núcleo y la que aún está por realizar se extiende en minutos, horas, dias, años y siglos, por lo que lo similar no parece nunca ser similar, pues en un caso sólo se considera el todo y en el otro partes aisladas". KOSELLECK, Reinhart. Futuro Pasado. Para una semántica de los tiempos históricos. Barcelona: 1993. p.339.

27

KOSELLECK, Reinhart. Historia/historia.

Barcelona: Trotta, 2004. p.106. siempre con el fin de asemejarlos: en la España Vieja solo se reconoce una casta de Hombres, en la Nueva muchas, y diferentes; en la Vieja logran la Real presencia, en esta Nueva veneramos igualmente su Real Augusto Nombre, tributamos los mas reverentes obsequios, sacrificando Vidas, Haziendas, y Corazones, por mantener todos sin la mas leve mancha la fidelidad; en los Españoles heredada, y pasada en su substancia con Leche, y en los Indios adquirida, alimentada con la Católica Religión, y aumentada con las Honras, Privilegios, y Favores, conque su Majestad, como tan grande, favorece a estos Párvulos, como tan Prudente a estos inocentes, como a tan Magnánimo a estos pusilánimes, y como tan rico, y Poderoso Monarca, a estos miserables: por lo que Españoles, y Naturales son muy acreedores a la Real Piedad, y a que los Prelados Eclesiásticos cumplamos..."23 Lo que no está todavía presente en la percepción de Lorenzana es la dimensión temporal que caracterizaría propiamente a la noción de experiencia esgrimida por Koselleck y que comienza a desarrollarse en el lenguaje alemán entre 1760 y 1780.

En cada uno se esconde una experiencia ajena transmitida institucionalmente de generación en generación. Y lo propio de la sociedad moderna radicaria en generar su identidad a partir del movimiento que traza una diferencia con el pasado. Rompe, en ese sentido, la secuencia natural del recuerdo al transformarlo en historia. Crea su identidad en el ámbito de la temporalidad. De acuerdo con Luhmann tal cosa no tendría en sí mismo nada de extraordinario, ya que en términos de la teoría de sistemas, un sistema autoreferencial como es el de la conciencia individual construye su identidad a partir de una referencia al pasado, distinguiendo el antes y el después. ${ }^{24}$ Por esa razón el punto decisivo para la investigación teórica e histórica radicaría en saber cómo este procedimiento referido a los individuos aislados tendió a universalizarse, a convertirse en la experiencia de una sociedad.

Koselleck descubrió que la conjunción entre Geschichte e Historie se dio en el lenguaje alemán entre 1760 y 1780, coincidiendo además con la aparición del neologismo "filosofía de la historia" acuñado por Voltaire. 25 La historia como acontecer y la historia como conocimiento del pasado se imbricaron, dejando ver el germen de una nueva relación con la temporalidad. Esta experiencia se tradujo en el reconocimiento paulatino de que ya muy poco se podía aprender de la experiencia adquirida. En otras palabras, significaba que el pasado y el futuro se alejaban uno de otro: mientras el horizonte de futuro se expandia, el espacio de experiencia se estrechaba. ${ }^{26}$ En ese sentido, el conocimiento del pasado entendido como acumulación de experiencias útiles en el presente iba dejando su lugar crecientemente al neologismo "historia contemporánea". Acontecer y conocimiento del pasado se compactaron en la palabra Historia (Geschichte). Así, la identidad de la diferencia entre acontecer y acontecimiento adquirió la forma de un concepto singular universal: la Historia con mayúscula.

En este contexto se desarrolló un tipo de discurso histórico que funcionará como una forma especular que permite al presente reconocerse como diferente del pasado a la vez que le dice qué hacer, lo cual no deja de ser una paradoja. La formación de "la Historia como concepto-guía moderno" es observada primero al interior de la comunidad de los letrados en el marco del lenguaje político y social de la vida cotidiana. ${ }^{27} \mathrm{~A}$ continuación, la historia como un concepto estructurante de la nueva sociedad la deja ver como una entidad que aprendió a articularse a partir de un lenguaje temporalizado. Con el fin de dar sentido y orientación a experien- 
28

Aunque no puede soslayarse que al inicio de este análisis se dispone fuertemente de un discurso histórico particularista o "nacionalista".
29

Para historiadores que apelan todavía a explicaciones providencialistas se toparán con el problema de cómo conciliar voluntad divina con libertad o voluntad humanas. cias fundadas principalmente en el futuro desarrolló un nuevo lenguaje histórico. Pero, sin dejar de soslayar la paradoja inscrita en el hecho de que al tiempo que la escritura de la historia remite a las cosas del pasado para iluminar su futuro, al mismo tiempo está indicando que esas cosas han dejado de ser parte del presente.

Si aceptamos entonces que los historiadores modernos al esclarecer las relaciones del pasado con el presente trabajan con al menos tres tipos de conceptos (históricos, historiográficos y methistóricos) se advierte que la posibilidad de comparación está dada menos por la información documental que por las categorias a priori utilizadas. Son las que permitirian calibrar la especificidad y diferenciación de cada uno de los procesos, además, desde luego, de las relaciones de los procesos con la lengua propia.

En razón de lo anterior, y en vistas al examen de los diversos procesos examinados sobre la evolución del concepto Historia en Iberoamérica, lo más significativo será poder mostrar, de un lado las semejanzas (que pueden expresarse en un vocabulario compartido) y, del otro, las posibles diferencias que permitirán especificar la singularidad de cada experiencia. Ese ser distinto dentro de lo semejante, sería lo decisivo en esta investigación compartida. ${ }^{28}$

\section{HISTORIA Y FORMACIÓN DE UN NUEVO ESPACIO DE EXPERIENCIA EN IBEROAMÉRICA}

En la presentación de los resultados de la investigación en términos generales se puede decir que existe bastante coincidencia en relación con el esquema conceptual propuesto por Koselleck. Grosso modo el periodo se puede dividir en tres grandes etapas. En la primera domina un concepto clásico de inspiración ciceroniana que entiende a la historia como un género literario. En la segunda, impulsado sobre todo por los movimientos políticos y sociales, tenderá a asimilarse a la historia nacional. La ruptura con el pasado colonial y/o con el pasado no republicano estructura nuevas narrativas históricas cuyo sentido está dado principalmente por un futuro incierto, por un acontecer cuyo desenlace es desconocido por los participantes. Sin embargo, la apertura de un nuevo espacio de experiencia político no elimina automáticamente las formas de vida acuñadas en el pasado. Así, como se muestra en algunos casos, el futuro puede ser leído también a la luz de una historia providencialista. ${ }^{29}$ Finalmente, en tercer lugar se tiene el desarrollo de una historia universal o filosofía de la historia articulada a partir de nociones como progreso y civilización.

En el ámbito lusobrasileño se tiene durante la primera mitad del siglo XVIII un concepto de historia cargado de referencias clásicas y la centralidad de la historia sagrada. A continuación, con una referencia implícita a la revolución francesa, se extiende un periodo dominado por el concepto ilustrado de historia (1789-1823). Finalmente, el periodo subsiguiente, estará marcado por una nueva complejidad, nuevos debates, que hacen surgir nuevos diccionarios y la necesidad de una historia nacional.

Podría adelantarse así que la transformación semántica de la historia pasa a través de la reconfiguración de los proyectos imperiales español y porugués. Este momento denominado como un periodo de "transición" culmina durante los procesos de independencias. Durante esta fase el vocablo historia se transforma en un singular colectivo. Una de las cuestiones abiertas, no obstante, será saber si en la construcción de las nuevas narrativas se modifican no sólo los contenidos sino también las formas. La 
La cuestión fue planteada en su momento por WHITE, Hayden: (¿se puede alguna vez narrar sin moralizar?) El contenido de la forma. Narrativa, discurso y representación histórica. Barcelona: 1992. Michel de Certeau en "Historia y estructura" se preguntó igualmente por la manera como se realizó el paso de una historia como relación cronológica a una nueva historia estructurada temporalmente. En CERTEAU, Michel. Historia y psicoanálisis, entre Ciencia y Ficción. México, 2. ed., 2003. p.101-113.

31

Aristóteles. Poética. Buenos Aires: 2003. p.57.

"De lo dicho se deduce también que no es obra de poeta relatar hechos que sucedieron, sino lo que puede suceder, esto es, lo que es posible según la verosimilitud o la necesidad. El historiador y el poeta no difieren entre si porque el uno hable en prosa y el otro en verso, puesto que podrian ponerse en verso las obras de Heródoto y no serían por esto menos historia de lo que son, sino que difieren en el hecho de que uno narra lo que ha sucedido y el otro lo que puede suceder. Por lo cual la poesía es más filosófica y elevada que la historia, pues la poesia refiere más bien lo universal, la historia en cambio lo particular. Lo universal consiste en que, a determinado tipo de hombre, corresponde decir u obrar determinada clase de cosas según lo verosímil o lo necesario. A ello aspira la poesía, aunque imponga nombres personales. Lo particular, en cambio, consiste en decir, por ejemplo, lo que obró Alcibíades y qué cosas padeció".

\section{2}

Cicerón. De Oratote (46 a de C): "Historia vero testis temporum, lux veritatis, vita memoriae, magistra vitae, nuntia vetustatis, qua voce alia nisi oratoris immortalitati commendatur? Nam si qua est ars alia, quae verborum aut faciendorum aut legendorum scientiam profiteatur; aut si quisquam dicitur nisi orator formare orationem eamque variare et distinguere quasi quibusdam verborum sententiarumque insignibus: aut si via ulla nisi ab hac una arte traditur aut argumentorum aut sententiarum aut denique discriptionis atque ordinis, fateamur aut hoc, quod haec ars profiteatur, alienum esse aut cum alia aliqua arte esse commune"

33

Voltaire. El siglo de Luis XIV. México: 2. reimpressão, 1996. p.7 e p.10. KOSELLECK, Reinhart. Futuro Pasado. Para una semántica de los tiempos históricos. Barcelona: 1993. p.48-49.

\section{4}

Véase por ejemplo AYLUARD0, Clara García. Los Borbones y la Nueva España: El otro yo del Rey: Virreyes de la Nueva España, 1535-1821. México: 1996, p.43-57. La representatividad de este texto se apoya en su carácter de divulgación.

\section{5}

Se quiere ver modernidad donde sólo se trata de reformas modernizadoras. "La revisión del gobierno imperial realizada por los Borbones puede considerarse como una centralización del mecanismo de control y una modernización de la burocracia. La creación de nuevos virreinatos y de otras unidades de gobierno aplicó una planificación central a un conglomerado de unidades administrativas, sociales y geográficas y cul- cuestión es pertinente en la medida en que de acuerdo con los resultados pareceria que el molde ciceroniano continúa utilizándose en esta "modernidad", si bien en una versión amplificada dirigida a la formación de una nueva ciudadanía republicana. ${ }^{30}$

\section{Los diccionarios y la lengua: predominio de la historia-narración}

Valdei Lopes de Araujo y Joao Paulo Garrido Pimenta apuntan una nota sobre el uso de los diccionarios que conviene retener: éstos no retratan el uso del lenguaje en el momento en que aparece, sino tan sólo tienden a estabilizar el resultado de una contienda lingüistica previa. En relación con el concepto historia llama la atención, por ejemplo, que los diccionarios no detectan su transformación antes de 1850, ni tampoco incluso a fines del siglo XIX, como se destaca para el caso español.

En principio sobresale el aspecto distintivo de la historia: su carácter narrativo, y por tanto, literario, asi como su vocación de edificación moral. Por lo menos hasta las dos primeras décadas del siglo XIX se sigue evocando a dos de las autoridades intelectuales pertenecientes al mundo clásico grecolatino: Aristóteles ${ }^{31}$ y Cicerón ${ }^{32}$. Es probable que durante el periodo aparezcan manuales que recuerdan y exigen el respeto a las reglas para obtener la verdad de la historia. El canon es perfectible. Pero, en general, la naturaleza moral de la historia no se pone en tela de juicio. Incluso, Voltaire -creador de la noción de "filosofía de la historia" en deuda con Bossuet- espera obtener de la historia una moraleja para el presente. La Historie sigue siendo concebida como el repertorio de experiencias ajenas útiles para los momentos y la toma de decisiones difíciles. En ese sentido la historia relatada cumple también una función político-moral. Si bien, se va dejando ver ya que esta función la pueden cumplir sólo algunos de los siglos, como el "siglo de Luis XIV". Con ello se observa un acotamiento del pasado, aunque sin afectar la estructura narrativa que articula el discurso histórico. "No todo lo acontecido merece ser escrito. En esta historia me interesaré sólo por lo que merece la atención de todos los tiempos, que puede pintar el genio y las costumbres de los hombres, servir de ejemplo y fomentar el amor a la virtud, a las artes y a la patria", escribió Voltaire. ${ }^{33}$

\section{Reformas Imperiales, Ilustración e Historia}

Teniendo en cuenta la anterior la pregunta consiste en saber ¿Cuándo y en qué contexto la historia se constituyó en una denominación abstracta, universal, a la vez que singular? Más precisamente la pregunta se puede formular así: ¿En qué momento y en qué contexto el pasado y el futuro se coordinaron de una manera en la que se restó a la Historie su poder de ejemplaridad? Se trata de una cuestión relacionada con la producción de textos de historia pero quizás, sobre todo, con la forma como los agentes iban percibiendo el acontecer.

Es común asociar las Reformas Borbónicas con la "modernidad" ilustrada, ${ }^{34}$ sin advertir con frecuencia sus paradojas. ${ }^{35} \mathrm{Al}$ referirnos al concepto de historia se ha subrayado su carácter experiencial. Se trata ante todo de un concepto de temporalidad cuya explicitación sólo se consigue a través del recurso a metáforas espaciales de movimiento, aceleración, etcétera. Habría que ver, por tanto, cómo los borbones y sus funcionarios estaban experimentando el tiempo, o como éste se reflejaba en sus proyectos, para poder verlos como representantes genuinos de la formación de un nuevo espacio de experiencia. 
minó en el nombramiento de intendentes, agentes fundamentales del absolutismo" (89). Sin cambiar las condiciones de dominación, "modificó el carácter del Estado Colonial y el ejercicio del poder" (91). Pero pudiera ser, se sugiere, que esta política de centralización y planificación a ultranza tuviera un efecto paradójico, involuntario, al no hacer caso a la tradición, al ignorar y repudiar el pasado, como lo señala Lynch (91). "Los Borbones procedieron como si pudieran detener la historia, invertir el desarrollo de una comunidad y reducir a la categoria de subordinados a personas adultas" (91-2). LYNCH, John. El Estado Colonial en Hispanoamérica: América Latina, entre colonia y nación. Barcelona: 2001.

\section{6}

Véase GRAFTON, Anthony. Los origenes trágicos de la erudición. Breve tratado sobre la nota al pie de página. Buenos Aires: 1998.

\section{7}

Véase, GRELL, Chantal. L'Histoire entre érudition et philosophie. Étude sur la connaissance historique a l'age des Lumières. Paris: 1993. Para España, MARTí-AGUILAR, Manuel Álvarez. La Antigüedad en la historiografía española del s. XVIII: el marqués de Valdeflores. Málaga: 1996.

\section{8}

VOLTAIRE. El siglo de Luis XIV. México: 2a. reimpressão, 1996. p.357.

\section{9}

"...considerando el gran número de naciones, costumbres y religiones diferentes, se ve lo poco que representan sobre la tierra un molinista y un jansenista. Se sonroja uno entonces de su pasión vehemente por una secta que se pierde entre la multitud y la inmensidad de las cosas", VOLTAIRE. El siglo de Luis XIV. México: $2^{\text {a }}$. reimpressão, 1996. p.440.

40

Análogo a la moda actual respecto del uso del término "moderno".

41

Pedro José Chacón Delgado, (España).

\section{2}

Las Reformas Borbónicas tuvieron impacto en el caso argentino con la creación del Virreinato del Río de la Plata en 1776. Se trata de un hecho político y administrativo de gran relevancia que incluye la creación del orbe literario y la publicación de las primera gacetas hacia 1800 (E) telégrafo). Aunque no puede pasarse por alto que sigue dominando la taxonomía aristotélica que diferencia a la historia -saber de lo particular-, de la poesía -saber de lo general-. Al menos en el medio eclesiástico, como se deja ver en un testimonio de 1802.
Así, hemos de trasladarnos al espacio literario donde tiene lugar la producción de historias durante este periodo. En tal sentido quizá sea más relevante observar la creación de diversas Academias dedicadas a las Bellas Artes y a la Historia fundadas durante la segunda mitad del siglo XVII en Francia; y en España (1735), Portugal y Brasil (1720) y en otros lugares durante la segunda mitad del XVIII. Sin embargo, no por el hecho de su creación se puede observar una transformación semántica de la historia, aunque sí la profundización de una práctica de crítica textual renacentista al hacer extensivo el combate en contra de las historias fabuladas desde el siglo XVII. ${ }^{36}$

En cambio, a las Academias se les puede ver como un espacio en donde el cultivo de las artes y las ciencias dejó de ser un patrimonio exclusivo de los monarcas al incentivar la investigación y conservación de la Antigüedad. ${ }^{37}$ Su formación permitió además el desarrollo paralelo de la física o historia natural y el de una historia "juiciosa" del género humano. ${ }^{38} \mathrm{~A}$ lo anterior habría que añadir la expansión de la prensa periódica iniciada en Gran Bretaña en el XVII y en pleno desarrollo en el ámbito iberoamericano a partir del siglo XVIII. La prensa escrita proporcionó un espacio de comunicación propicio para desarrollar el arte de la comparación entre diversas culturas y para mostrar que toda la historia no era reducible a acciones individuales, por más grande que fueran. El incremento de la información acerca de la vida y situación de otros pueblos y culturas permitió desarrollar además una mirada irónica sobre lo propio y lo más inmediato. La contemplación de "la historia general del mundo" hacia ver que las disputas locales no eran tan determinantes como podrian parecer a simple vista. ${ }^{39}$

Por tanto, quien disponía de una visión cosmopolita podría decirse que tenía un "espíritu ilustrado", término de moda cuando se llevan a acabo las famosas reformas impulsadas por los Borbones durante la segunda mitad del siglo XVIII.40 La experiencia de viaje, el desarrollo de la prensa periódica y el espiritu inquisitivo universalista están presentes en uno de los productos más emblemáticos de la "Ilustración": la Encyclopedie (1751) de Diderot y D'Alambert. Y es verdad, como se destaca para el caso iberoamericano, que esta impronta distingue a un letrado tan influyente como Gregorio Mayans y Siscar. Como lector de la Enciclopedia un año después de su aparición en 1751, Mayans divide a la historia en humana y sagrada, y la humana a su vez, en literaria, natural y civil. ${ }^{41}$ Sobre esta base se desarrolla el estudio del pasado que incluye la revisión de los orígenes del Imperio en el siglo de la conquista. Se corrigen y escriben nuevas, pero en lo fundamental se hacen para actualizar ese pasado glorioso, hacer un llamado a la unidad de los mundos tan diversos que lo componen, y confirmar ante todo a la dinastía reinante en un momento de cambio. 42

¿La importancia de la historia natural y la aparición de la historia universal o "historia sin más" inaugurada por Bossuet y proseguida por Voltaire refieren a la formación de un nuevo campo de experiencia? No necesariamente, en el sentido de ofrecer una nueva manera de coordinar las relaciones entre pasado y futuro. Es verdad que durante la segunda mitad del siglo XVIII se realizan numerosas expediciones científicas. La Corona española envía a funcionarios civiles y eclesiásticos para supervisar y reestructurar las fronteras geográficas y culturales de sus dominios. Para el caso de Argentina, Félix de Azara (Descripción e historia del Paraguay y del Río de la Plata, 1790); Chile, Vicente Carvallo y Goyeneche (Descripción histórico-geográfica del Reino de Chile, 1795); México, Alejandro de Humboldt, (Ensayo político sobre el reino de la Nueva España, 1805); Venezuela y 
43

Chile: MOLINA, Juan Ignacio. Compendio de la Historia Civil del Reyno de Chile, 1795; Colombia: GILIJ, Felipe Salvador. Ensayo de Historia Americana, Estado presente de la Tierra Firme; México: CLAVIJERO, Francisco Javier. Historia antigua de México. 1780. La "modernidad nacionalista" las acogerá como precursoras de las nuevas historias.

\section{4}

Véase el libro de CAÑIZARES-ESGUERRA, Jorge. How to Write the History of the New World. Histories, Epistemologies, and Identities in the Eighteenth-Century Atlantic World. Stanford: 2001. Queda la impresión de que su recorrido está todavía cifrado por la impronta nacionalista. En ese sentido no consigue ser un texto de genuina crítica postcolonial. Da continuidad, en buena medida, a una épica criolla construida alrededor de una historia de las ideas.
Colombia, José Gumilla (El Orinoco ilustrado y defendido, 1741) y Alejandro de Humboldt (Viaje a las Regiones Equinocciales del Nuevo Continente, 1816- 1826). Para el caso de la Corona portuguesa, Damião de Lemos Faria Castro, (História geral de Portugal e suas conquistas oferecida à Rainha Nossa Senhora D.Maria I, 1786-1804). Se revisan los escritos de los antepasados y se rectifican las historias ya escritas.

Las monarquías, española y portuguesa, es verdad, se miran a sí misma de cara al futuro; pero este futuro se piensa más en términos de conservación y prolongación, no tanto de su transformación. Asimismo, las historias naturales en sentido estricto no son obra de "historiadores". La historia en el conjunto de las artes y ciencias del periodo es sólo un saber particular que cumple una función generalmente asociada a la perfectibilidad del género humano. Incluye una perspectiva de futuro, pero se trata de un porvenir que se reconoce todavía en el pasado. Se trata en esencia de un "futuro pasado" capaz de ser recreado por obra de los historiadores. La historia como un género literario, en ese sentido realiza un trabajo paralelo al de los naturalistas.

La impronta "enciclopedista" de Mayans se advierte especialmente en la década de 1780 . Se refleja en la necesidad de programar una historia de la nación española incluidas todas sus demarcaciones. Y curiosamente quienes realizan esta tarea en algunos casos son jesuitas que fueron expulsados de los dominios de la Monarquía en 1767.43 Surgen bajo el sello de la polémica al cuestionar las historias críticas ilustradas de autores como el Abate Guillaume-Thomas Raynal, Histoire Philosophique et Politique des établissements et du comerce des Européens dans las deux Indes (1770), William Robertson, The History of America (1777) y Cornelius de Pauw, Recherches philosophiques sur les américains, ou Mémoires intéressants pour servir à l'histoire de l'espèce humaine (1768-69). Apoyados en la figura del testigo presencial como autoridad argumentan en contra de las narraciones históricas que denigran a las naciones de raices iberoamericanas. Ahi comienza a prevalecer, como se destaca también para los casos metropolitanos (Madrid y Lisboa), la historia civil.

A fines del siglo XVIII sigue dominando el carácter narrativo de la historia. Dicha forma, sin embargo, comienza a ser afectada por las reformas disciplinarias impulsadas por autores como Gaspar Melchor Jovellanos (Sobre la necesidad de unir al estudio de la legislación el de nuestra historia, 1780), Juan Pablo Forner, (Discurso sobre el modo de escribir y mejorar la historia de España, c.1788) y Juan Sempere y Guarinos, (Reflexiones sobre el buen gusto en las ciencias y en las artes, 1782). ${ }^{44} \mathrm{En}$ el trasfondo destaca la figura de Francis Bacon y su Novum Organum. Esta marca es visible en el ámbito americano en el Mercurio Peruano (1791-1795) y más tarde (haciendo ver una línea de continuidad entre uno y otro siglo) en José Manuel Valdez y Palacios (Bosquejo sobre el estado político, moral y literario del Perú en sus tres grandes épocas, 1844). El Mercurio hace eco de Jovellanos: "En nuestras crónicas, historias, anales, compendios y memorias (...) Se encuentran, sí, guerras, batallas, conmociones, hambres, pestes, desolaciones, portentos, profecias, supersticiones (...) Pero ¿dónde está una historia civil, que explique el origen, progresos y alteraciones de nuestra constitución, nuestra jerarquía política y civil, nuestra legislación, nuestras costumbres, nuestras glorias y nuestras miserias?" Así, para el caso de Perú, pero quizás también para otros de las antiguas colonias, no es fácil separar el desarrollo de la historia en América de la peninsular. 
45

VISCARDO Y GUZMÁN, Juan Pablo. La paz y la dicha del nuevo siglo. Exhortación dirigida a todos los pueblos libres o que quieren serlo, por un americano español. (1797). Obra completa en dos volúmenes (Lima: Congresso del Perú, 1998).

\section{6}

Idem. Ensayo histórico sobre los disturbios de América Meridional en el año 1780. In: La paz y la dicha del nuevo siglo. Exhortación dirigida a todos los pueblos libres o que quieren serlo, por un americano español. (1797) p.43-57.

\section{7}

Valiosos testimonios de la recepción y utilización de la Carta se encuentran en el volumen 2 de las Obras Completas de Viscardo. Idem. Obra completa. Lima: Congreso del Perú, 1998.

48

Idem. Carta a los españoles americanos (Traducción del manuscrito francés hallado en Nueva York), 1799. In: ______. Obras completas. p.205. (resaltado en el original)

\section{Interludio político e intelectual}

Las obras históricas de filósofos ilustrados como Raynal y Robertson reaparecieron después de los acontecimientos de 1789, pero en un contexto político diferente. Esta situación refiere no sólo a la toma de la Bastilla, sino también a la independencia de las 13 colonias inglesas de América (1776). La evocación a dichos sucesos contiene la carga de un futuro posible. Este pasado inmediato dice cómo podría o debería ser el porvenir. Esta consideración forma parte de la argumentación de otro jesuita expulso, originario de Arequipa en Perú, pero situado en Londres y no en Italia, Juan Pablo Viscardo y Guzmán. Viscardo murió en Londres en febrero de 1798 sin haber visto publicada su famosa Carta a los españoles americanos en 1799. Su contenido está inspirado en la obra del abate Raynal, por un lado, y del otro, la escribe de cara al siglo que apenas empieza. Como hijo de español nacido en suelo americano se identifica con la causa emprendida por los colonos norteamericanos: desde ahí plantea la posibilidad de la independencia de las colonias hispanoamericanas por medios pacíficos. ${ }^{45} \mathrm{En}$ su proclama asume agravios cometidos durante los disturbios de 1780 en América Meridional. ${ }^{46}$ La Carta es famosa porque será difundida y utilizada a partir de 1799 por el General Francisco Miranda, ubicado también como Viscardo en Londres, y más tarde en Venezuela durante la guerra de independencia a partir de $1810 .{ }^{47}$

Viscardo argumenta históricamente al señalar que el Imperio español no se estaba comportando a la altura, tomando como modelo la relación que los griegos establecieron con sus colonias. En este procedimiento la historia es todavía un depósito de experiencias útiles para el presente. Sin embargo en ese contexto letrado lo que salta a la vista es la manera como se refiere a los tres siglos de la presencia de España en suelo americano. Me permito citarlo en extenso dada su importancia:

\footnotetext{
La proximidad en que nos encontramos del cuarto siglo después de que nuestros ancestros comenzaron a establecerse en el Nuevo Mundo, es un acontecimiento demasiado notable para no atraer más seriamente nuestra atención. El descubrimiento de una tan grande parte de la tierra es y será siempre para el género humano, el acontecimiento más memorable en sus anales; pero para nosotros que somos sus habitantes, y para nuestros descendientes, es un tema de suma importancia. El nuevo mundo es nuestra Patria, su historia es la nuestra, y es en ella que todos nuestros deberes esenciales, nuestros más caros intereses, nos obligan a examinar y a considerar atentamente el estado de nuestra presente situación y las causas que en ella más han influido, para resolvernos luego, con pleno conocimiento, a tomar valientemente partido que nos dictarán nuestros indispensables deberes hacia nosotros mismos y nuestros sucesores.

Apesar que nuestra historia de tres siglos, en lo que respecta a las causas y efectos más dignos de atención, sea tan pareja y conocida que pueda ser abreviada en las cuatro palabras siguientes: Ingratitud, Injusticia, Esclavitud y Desolación, nos conviene leerla más detenidamente. ${ }^{48}$
}

Si no yerro, inspirado en el texto de Raynal, Viscardo está inaugurando el tema de los 300 años de opresión que reverberá de muchas maneras en las dos décadas siguientes: como slogan de los insurgentes americanos y como una frase inscrita en las actas de independencia. Lo más relevante, empero, consiste en que ese pasado trisecular ha perdido su carácter de ejemplaridad, haciendo ver un estrechamiento del espacio de experiencia al lado de un ensanchamiento del horizonte de expectativas, en términos polí- 
49

Utilizado por Fray Servando de Teresa de Mier en México. Cf. BRADING, David. Orbe indiano. De la monarquía católica a la república criolla, 1492-1867. México: 1991. p.638-640.
50

Victor Samuel Rivera (Peru) ticos y sociales. Esa nueva relación entre el pasado y el futuro se sustenta, como se dijo, en los eventos fundadores de 1776 y 1789.

Esta consideración no deja de lado el hecho de que muchos de estos impresos y manuscritos fueron proscritos y perseguidos por la inquisición en México, ${ }^{49}$ y en Perú sólo fueron conocidos hasta después de 1824. Así, hay que añadir que muchos de estos textos comienzan a tener relevancia hasta después de las independencias. Se conoce todavía poco -salvo algunas excepciones- sobre su impacto entre sus contemporáneos. Quizá, Viscardo sea una de las excepciones: su Carta fue utilizada desde Londres para alentar y promover la idea de la independencia siguiendo el ejemplo angloamericano, favorecida estratégicamente por los británicos. Viscardo se relaciona con los trabajos de Clavijero y otros jesuitas expulsos solamente en el aspecto de combatir los prejuicios europeos sobre el continente americano. Para ello siguen acudiendo a un principio de autoridad antiguo: la figura del testigo presencial de aquello que se narra. El testimonio de Viscardo coincide además con el clima intelectual de la época. Hacia 1800 en Europa no se habla de un nuevo renacimiento, sino del comienzo de algo nuevo, sin precedente en el pasado.

No obstante, en cuanto a la argumentación histórica, se oscila entre la evocación a los hechos remotos de la antigüedad clásica y los contemporáneos. Y la historia continúa siendo en esencia un concepto moral más que político que presupone la diferencia con la historia natural, ya que en esta última se desconoce el libre albedrío. Esta noción de historia civil o moral incluye, por tanto, la noción de perfectibilidad, regulada por modelos preestablecidos, que invitan a la imitación más que a la modificación de la historia. Sólo lo humano es perfectible, a diferencia de la historia sagrada que es perfecta por naturaleza divina. Esta noción tendería a fracturarse durante el siglo XVIII alemán cuando la Biblia y la teología se convirtieron en objetos del análisis histórico; cuando Herder declaró que la Biblia tenía también una historia. En cambio, en el contexto iberoamericano, la fractura provendría más bien de eventos políticos y sociales que propiamente intelectuales. En ese sentido, es verdad que en el ámbito iberoamericano no se tiene a la mano una elaboración crítica de una noción de historia como Magistra vitae, y por consiguiente, no seria pensable la apertura de un nuevo espacio de experiencia. ${ }^{50}$ Aunque cabría pensar en la conveniencia de ampliar el repertorio de las fuentes utilizadas para verificar tal afirmación. En todo caso parece ser que a todos los casos tratados los reúne un común denominador: no tanto la Revolución francesa y el movimiento de la llustración en sí, sino los efectos de las guerras europeas desatadas por Napoleón en los dominios iberoamericanos. Sus repercusiones serán todavía más notables a partir de 1820: el círculo de la narratología histórica clásica tendería entonces a romperse.

\section{Los procesos de independencia y "los 300 años de opresión"}

Recordando la hipótesis central que da marco a esta investigación, Koselleck señala que hubo un momento en el que se observa en el lenguaje alemán una intersección lingüistica. Hay un lapso en el que se cruzan la Geschichte -la historia como acontecer reflejada en los sucesos (Ereignis) - y la Historie, entendida como informe y representación verbal o escrita de los sucesos. La historia como saber de las cosas del pasado para ilustración del presente (Magistra vitae) se fusiona con el acontecer mismo, de tal modo que el futuro tiende a nutrirse del presente, más que del pasado lejano. La 
51

Al respecto véase el sugerente estudio de PIMENTA, João Paulo Garrido. Brasil y las revoluciones de Hispanoamérica (1808-1822). In: CALDERÓN, María Teresa; THIBAUD, Clément (Org.). Las revoluciones en el mundo atlántico. Bogotá: Taurus, Universidad Externado de Colombia, 2006. PIMENTA, João Paulo G. . Brasil y las independencias de Hispanoamérica. Castelón: Publicacions de la Universitat Jaume I, 2007. p.13-29.

\section{2}

¿Qué implicaría una tal elaboración?, es una cuestión abierta. Está, por lo pronto la propuesta de CAÑIZARES-ESGUERRA, Jorge. How to Write the History of the New World. Histories, Epistemologies, and Identities in the Eighteenth-Century Atlantic World. Stanford: 2001. Y por supuesto las versiones nacionalistas ampliamente difundidas de la "intelectualidad criolla" como precursora de la independencia.

53

Cf. LYNCH, John. Las raíces coloniales de la independencia: América Latina, entre colonia y nación. Barcelona: 2001. Si bien Lynch matiza a establecer que en esos años previos a las independencias había venido cambiando la "conciencia política" (p. 163)

\section{4}

Angel Rafael Almarza Villalobos, (Venezuela).

\section{5}

BREÑA, Roberto. El primer liberalismo español y los procesos de emancipación de América, 1808-1824. Una revisión historiográfica del liberalismo hispánico. México: 2006. p.225-235. fusión del acontecer con el saber en el presente se manifiesta en el término Geschichte, que deja atrás la forma plural de las Historien y se convierte en un singular universal. Este fenómeno ocurrió de manera más tangible alrededor de 1800. Retrospectivamente, podría aparecer sólo como un interludio en cuanto a la proximidad que alcanza la historia con la filosofía o la poesía. Independientemente de ello, lo más importante en la tesis de Koselleck radica en el hecho de que con la aparición del neologismo Historia (Geschichte) (que implica al mismo tiempo saber de la historia y hacer la historia) aparece la formación de un nuevo espacio de experiencia conocido como "moderno".

En general habria coincidencia en que este cambio tuvo lugar en el medio lberoamericano entre 1808 y 1823, propiciado no tanto por un movimiento intelectual como por movimientos sociales y politicos que originaron la desarticulación del imperio español y portugués. ${ }^{51}$ Así, los cambios políticos son los que movilizan la transformación semántica de la historia, sin que exista de por medio una elaboración intelectual previa. ${ }^{52}$

Es evidente asimismo que la cronología de esta transformación no es la misma para cada una de las regiones examinadas. A la luz de una historia económica y de las ideas, por ejemplo, las modificaciones sociales se sitúan básicamente durante el periodo de las reformas borbónicas. Estas medidas presuntamente habrian roto los lazos sociales entre diversos estamentos y producido un nuevo tipo de "colonialismo", el cual sería la causa directa de los procesos de independencia. 53 Es innegable que esta descripción se corresponde con el planteamiento de Viscardo y Guzmán inspirado en autores como Raynal, Montesquieu y Thomas Paine. Pero el asunto que ya no es tan claro es la relación entre este argumento y el curso de las acciones que originaron el desmoronamiento del imperio español y portugués. Si el análisis ideográfico permite atisbar una línea de continuidad entre el periodo de las reformas borbónicas y el de las independencias, por el contrario un análisis histórico conceptual deja ver más bien que hay razones suficientes para pensar que solamente es a partir de 1808 con las Cortes de Cadiz (como efecto de la invasión francesa en España) que aflora la posibilidad de la creación de un nuevo espacio de experiencia con implicaciones en nuevos usos de la temporalidad. La historia, a partir de entonces parece correr más de prisa, y así los patrones clásicos de calcular el tiempo tienden a volverse obsoletos. Sería un momento en el que las relaciones entre pasado y el futuro se dislocan, se tornan discordantes.

Para el caso de Venezuela se encuentran expresiones sintomáticas de este cambio. Miguel José Sanz, amigo de Francisco de Miranda, utiliza en 1810 la metáfora de la orfandad para describir la situación de la nación: se han quedado sin padres y, por tanto, sin la tutela natural. En un diario de 1811 puede leerse la expresión formulada por Viscardo y diseminada por Miranda acerca del imperio que ejerció su dominación con gran "ferocidad por más de 300 años". Esta fórmula se pone de moda durante las guerras de independencia hasta quedar consagrada en algunos casos como en el de Venezuela y México en el Acta constitucional. ${ }^{54}$ Y para nuestra sorpresa es posible encontrar esta expresión de los "300 años" en el campo "contrario" aunque con otra carga valoral. El español Francisco Martínez Marina, representante en las Cortes de Cadiz, en dos textos de 1808 y 1813 se vuelve al pasado español para rescatar todo lo bueno que ahi se encuentra para construir una monarquía republicana. 55 Lo anterior nos indica dos cosas: 1) el pasado se ha vuelto ambiguo $y, 2$ ) sobre un doble anacronismo de signo 
Esta situación la he desarrollado más ampliamente en mi artículo en prensa, "Apropiación del pasado, escritura de la historia y construcción de la nación en México".

57

SCHMIDT, Peer. Siéndome preciso no perder minuto. Percepción del tiempo en México (18101910). mecanuscrito inédito.

58

En la línea apuntada por Joao Paulo Pimenta: "Dicho de otra manera, defiendo que la creación de una idea de historia de Brasil, con rasgos específicos con relación a la historia de Portugal, fue uno de los motores del desarrollo y viabilización del proyecto político de la independencia". En "Espacios de experiencia y narrativa historiográfica en el nacimiento del Brasil independiente (Apuntes para un estudio)". In: Brasil y Las Independências de Hispanoamerica. Castelló de La Plana: Publicacions de La Universitat Jaume I, 2007. p. 135 contrario se está erigiendo un nuevo régimen de historicidad. ${ }^{56} \mathrm{El}$ pasado reflejado en el presente como un espejo ha comenzado a desquebrajarse.

No obstante, esta situación presenta una paradoja. Los tres siglos que preceden a 1789 no pertenecen a los tiempos modernos, sino a una borradura. Este borrón y cuenta nueva señala la anulación del pasado como un pasado ejemplar, y el predominio del presente orientado hacia un futuro ejemplarizante. Señala la formación de un espacio de experiencia que no ha germinado fundamentalmente en el campo de las letras sino en el terreno de la formación de un nuevo lenguaje político y social. Esos "300 años" no se parecen en nada a lo que apenas está naciendo y cuyo desenlace es incierto para la mayoría de los agentes. En ese sentido, aquello que va tomando forma sólo se parece a sí mismo. Se presenta un escenario en el que la historia está en vilo.

Durante este lapso se muestra también cómo ya desde el verano de 1808, frente a los eventos de la abdicación de Carlos IV y Fernando VII, las autoridades en diversas capitales virreinales dejan ver su nerviosismo frente a la aceleración de los eventos y la falta de información acerca de lo que está sucediendo en Europa. Hay testimonios en los que se advierte que la experiencia acumulada de varios siglos ha dejado de ser funcional para el presente, una actualidad que se proyecta en términos de horas, días, años. Expresiones de este estado de ánimo se encuentran en la Historia de la revolución de Nueva España de Fray Servando Teresa de Mier al utilizar frecuentemente el término aceleración y sus sinónimos. Otro testimonio de 1813 exclama: "El grito de libertad que se dio en Dolores la noche del 15 al 16 de septiembre de 1810, por el inmortal héroe don Miguel Hidalgo y Costilla se extendió con la rapidez del rayo por todos los confines del venturoso Anáhuac, que se hallaba sepultado en duro cautiverio casi por tres siglos". 57 Así, las observaciones de Peer Schmidt coinciden con la hipótesis general de este ensayo: que la apertura de un nuevo espacio de experiencia se vincula directamente con los cambios políticos y sociales que emergen con los movimientos de independencia. Esta anotación es relevante en la medida en que durante el periodo anterior la historia se debe ante todo a las letras, la literatura, la educación del príncipe y de sus súbditos

Sin embargo, no hay que esperar que la formación de esta nueva experiencia del tiempo se generalice con la misma "velocidad del rayo" al todo social. Es fácil por ello circunscribir esta experiencia a un puñado de funcionarios y activistas políticos, sociales y militares. De otra manera estos sectores no se hubieran preocupado relativamente pronto en emprender campañas de "moralización" para construir un nuevo tipo de ciudadanía, para generalizar dicha experiencia. Este ímpetu "civilizatorio" deja ver en esencia que se trata de un proyecto de futuro. Y simultáneamente se intentará descubrir en el pasado aquellas "experiencias" análogas a las del presente. Es el momento en que las trayectorias de las sedes imperiales y coloniales tenderán a bifurcarse. ${ }^{58}$ Cada una de las sedes metropolitanas y subalternas construirán a su modo una plataforma que restaure o invente de nuevo la imagen especular de la historia. Se trata ya en si mismos de gestos modernistas: el pasado es movilizado en función de un futuro abierto, cuyo desenlace es desconocido por igual para cada uno de los participantes. Esta nueva experiencia quizás no impide la supervivencia de la vieja historia. Regresa la historia como espejo del presente, pero seguramente con nuevos contenidos. La pregunta es saber si este movimiento implica también la transformación de las formas de escriturar la historia. 
59

Para el caso peruano cf. Javier Fernández Sebastián, artículo sintesis sobre liberal/liberalismo.

\section{0}

Por ejemplo, el español DE LA ROSA, Francisco Martínez. ¿Cuál es el método o sistema preferible para escribir la historia? Revista de Madrid, segunda serie, tomo II, 1839.

61

DE LA ROSA, Francisco Martinez. El Espíritu del Siglo. Madrid: BAE, 1960-62 (vols. V-VIII), (citas tomadas de Manuel Moreno Alonso:1979.)

\section{Aparición y predominio de la historia contemporánea}

En el contexto de las crisis imperiales se desarrolla el neologismo histórico de historia contemporánea. Encuadrada por la crisis política y social aparece una noción que se escucha en México, Argentina e incluso en Perú ya en 1812: la historia de los últimos años es más generosa en enseñanzas que toda la historia anterior. ${ }^{59}$ Su presencia en el vocabulario de la época es un síntoma de la distancia que separa a sus portavoces de la experiencia de otros tiempos, dejando ver la pérdida de aura de las historias remotas, clásicas, renacentistas o medievales. Esta nueva experiencia, a su vez, va sentando las bases para la emergencia del pasado como objeto de investigación, un pasado que ya no es capaz de modelar el presente, aunque sí susceptible de ser conocido. Así, es importante observar - como se deja ver en varios autores, peninsulares y no peninsulares- 60 que paulatinamente la única historia capaz de enseñar algo es la historia contemporánea, sobre todo las historias de índole política y militar. "iAy de la América si no aprovecha el estudio de la historia contemporánea!" se lee en un semanario mexicano en 1826. 0 en España "La historia de los últimos cincuenta años encierra más lecciones de política que la larga serie de muchos siglos; pero puede afirmarse, sin temor de ser desmentido, que si las naciones han aprendido poco en la escuela de la adversidad, menos tal vez han aprendido los gobiernos. No es extraño que se oigan con indiferencia las severas lecciones de la historia, y que buscando excusas en la diversidad de los tiempos y de circunstancias, no se haga la debida aplicación de verdades muy importantes, pero que se olviden tan en breve unos desengaños tan amargos; que se cierren los ojos para no ver los hechos que están pasando a nuestra vista, y que en vez de poner de manifiesto la causa de tantos males para aplicar el remedio oportuno, se quieren perpetuar las antiguas dolencias, apenas parecerá creible a la posteridad".61

La ascendencia de la historia contemporánea, amplificada por el surgimiento de "historias filosóficas", se convirtió en el tribunal de justicia del mismo proceso, abriendo una grieta creciente entre el pasado tenido como autoridad y el presente establecido como potestad de sí mismo. Se trata de un nuevo programa de historia que atañe especialmente al ámbito de la historia civil y política, y por lo tanto, que acompañará de cerca a la construcción y resemantización de otros conceptos, como el de nación. Este programa a su vez requerirá de la formación de un nuevo tipo de relato histórico, y así de un programa de formación de un nuevo tipo de historiadores al servicio de la nación. Esta necesidad se hace explícita hacia 1850, por ejemplo, en Argentina en voz de Bartolomé Mitre al fundar el Instituto Histórico y Geográfico del Río de la Plata.

\section{La historia como concepto político}

A partir de 1820 se generaliza la noción de historia como un concepto político. Nada simboliza mejor este hecho que la auto-coronación de Napoleón el 2 de diciembre de 1804 en Notre Dame: su autoridad dimana de si mismo y sólo tiene como espectadores a las autoridades tradicionales (dinastía, herencia, papado). La selfmade history tiene el poder de inaugurar una nueva tradición dinástica. Dado que el pasado ha dejado de informar al presente, que los modelos tradicionales del hacer y el deber ser han sido desactivados desde la nueva realeza, es necesario dotar de leyes y autoridad (legitimación) al nuevo Estado. Surgen el código civil, penal, etcétera. El espíritu reformista informa a la sociedad y se hace necesaria la Constitu- 
62

BARQUERA, Juan Maria Wenceslao. Lecciones de politica y derecho público para instrucción del pueblo mexicano. México: edição fac-similar, 1991. ción. Junto con ello se inaugura asimismo un nuevo régimen de historicidad (Hartog). Pero, como se ha sugerido, se trata solo de una de las caras del proceso. Habría que examinar como esta "modernidad" está siendo incorporada por los distintos sectores sociales. Lo decisivo, en cualquier caso, consistirá en preguntarse cómo los diversos agentes viven y procesan de ahora en adelante la historia.

En América se lee a los autores españoles, pero esas lecturas se enriquecen además con las propias, generalmente escritas desde fuera del pais. En la producción de ideas y, en consecuencia, en el debate conceptual, domina la historia civil y eclesiástica, alimentada desde el siglo XVIII por el desarrollo de la prensa periódica. Pero la historia, si bien es importante, no parece tener una centralidad tal como comenzará a observarse a partir de la crisis de los regímenes imperiales, a comienzos de la década de 1820. Desde entonces se le dota al vocablo historia un poder casi demiúrgico, sólo equiparable al que puede seguir teniendo la pastoral eclesiástica. Este nuevo poder de la historia se documenta en un escrito publicado en México en 1822. ${ }^{62}$ Ahi se establece que no hay buena política sin historia y viceversa. Este axioma, es verdad, recuerda al Jovellanos de 1780 al suscribir que el buen accionar de la política descansa sobre el conocimiento del derecho y de la historia.

A partir de entonces se tiene un redimensionamiento de la historia integrado cada vez más en el vocabulario político y social. Esta tendencia culmina, como se ha señalado para otros casos, en la escritura de una historia nacional canónica: Brasil: Francisco Adolfo de Varhagen,"Historia Geral do Brasil" 1854-1857; Colombia: José Manuel Restrepo, Historia de la Revolución en Colombia (1827); Chile: Claudio Gay, Historia física y política de Chile $(1846,1852) ;$ España: Modesto Lafuente, Historia General de España, desde los tiempos más remotos hasta nuestros dias (1850); México: Lucas Alamán, Historia de México desde los primeros movimientos que prepararon su independencia en el año de 1808 hasta la época presente (1849-1852); Perú: José Manuel Valdez y Palacios, Bosquejo sobre el estado político, moral y literario del Perú en sus tres grandes épocas, 1844; Portugal: Alexandre, Herculano, História de Portugal desde o começo da monarquia até ao fim do reinado de Afonso III (1846-1853); Venezuela: Feliciano Montenegro y Colón, Historia de Venezuela (1837) y Rafael María Baralt, Resumen de la Historia de Venezuela (1841). Al respecto Argentina parece ser la excepción a la regla. Durante el periodo no hay una historia semejante, si bien el camino está empedrado de reflexiones para establecer el programa de una historia nacional futura.

Dentro de una perspectiva de larga duración queda la cuestión acerca de si estas historias nacionales constituyen auténticos "puntos de partida" o se podrian ver como el cierre de un periodo. Por lo pronto se trata en general de historias modeladas bajo un espíritu liberal más que providencialista. No obstante, estas historias no descartan la presencia de enfoques providencialistas. No se trata de una contradicción, sólo se revela la separación tradicional entre una historia escrita por Dios, perfecta y completa por naturaleza, y una historia humana incompleta y abierta a la acción libre del hombre. El sentido universalista de la nueva historia incluye dentro de su repertorio toda clase de historias; pero sujetas ahora a un nuevo orden de historicidad, como se consigna en un testimonio de Juan Donoso Cortés de 1838: "Si el género humano, en fin, tiene una historia de la que las historias particulares son fragmentos, ¿las revoluciones que en ella se consignan, 
Citado en Citado por CHACÓN, Pedro José. E concepto de Historia en España (1750-1850). Araucaria, n. 17, p.15. 2007.

64

LISTA, Alberto (1830). Sobre el estudio de la historia de España. Gaceta de Bayona, no 141, 5 febrero. riencia religiosa) también se vea afectada. las catástrofes que en ella se describen y el movimiento progresivo que en ella se advierte, son obra de la casualidad o efectos necesarios producidos por principios necesarios también y por leyes providenciales y eternas?".63 El concepto de una historia intrínseca al mismo devenir histórico es articulado también por Alberto Lista en 1830: "A este importante estudio [de la historia] están ligados el de los diferentes caracteres y espiritus de las naciones, sus recursos en población y riqueza, su educación religiosa y civil, sus juegos, sus espectáculos, sus ciencias y artes, sus vicios y virtudes, sus errores y preocupaciones; en fin, todo lo que pertenece a la humanidad (...) Si el estudio de este ramo interesante de conocimientos es necesario al filósofo racional, al moralista, al político, al guerrero y al literato, mucho más lo será el de la historia patria, que es el que más le importa conocer: porque si es cierto que la edad presente está preñada de la futura, también lo será que en los sucesos pasados está el germen de la actual situación de las naciones, en la cual puede el hombre reflexivo prognosticar hasta cierto punto cuál será su suerte futura; y de ningún pueblo le importa tanto hacer esta especie de horóscopo como del suyo propio".64

\section{La historia como filosofía de la historia}

Como se deja ver, la centralidad de la historia durante este periodo se proyecta en un concepto filosófico de la historia. Sin embargo, conviene distinguir esta noción de las "historias filosóficas" de los philosophes franceses. El nuevo sintagma pasa a ser parte del vocabulario sociopolítico a partir de la década de 1830. La historia deja de ser una mera narración de sucesos y se transforma en un conjunto de nuevas experiencias y categorias explicativas. Es significativa, por ejemplo, la evolución respecto a la distinción entre historiógrafo (anticuario) e historiador moderno. Mientras el historiógrafo refiere sucesos, reúne materiales, el historiador selecciona, ordena, examina los hechos, juzga a los hombres y sus cosas. El historiador suele ser menos adulador y más imparcial que el historiógrafo. Un diccionario de 1850-53 ha acabado por estabilizar en Brasil el nuevo concepto de historia entendido como un singular colectivo.

Parece haber una coincidencia en casi todos los trabajos: Io político y lo social, más que los lenguajes puros, son detonadores de la necesidad de buscar nuevas fórmulas para describir las nuevas situaciones. El surgimiento del nuevo concepto de historia en Alemania en su búsqueda del origen de sí misma, en cambio, se relaciona además con una reacción germánica frente a la influencia latina (Herder). La Historie latina tenderá a ser sustituida por el vocablo alemán Geschieht. No parece encontrarse una reacción similar en el ámbito iberoamericano. Incluso el abandono del latín como lengua franca a favor de las lenguas vernáculas pasa indefectiblemente por el tamiz o huella impresa del latín.

En ese sentido se postularía que la aparición de una nueva noción de Historia, como la del neologismo Opinión pública, se presenta como una forma de enfrentar y resolver los nuevos problemas del ejercicio y representación de la autoridad pública. En el caso de la Opinión Pública ésta deviene en sustituto del Soberano ausente o Cabeza del organismo social. En el caso de la Historia, ésta se presenta como una forma de responder a un futuro incierto, es decir, un futuro que ha dejado de pautarse en lo social y en lo político -no así en lo religioso- por el pasado. ${ }^{65}$ Se trata de un lapso en el que el pasado se ha vuelto cuestionable $y_{1}$ por tanto, ha dejado de ser modelo de imitación. De manera más específica, el nuevo concepto de 
HAZARD, Paul. La crisis de la conciencia europea 1680-1715. Madrid: 1988. historia surge como una reacción en contra de la historia humanista plasmada durante el Renacimiento, por un lado, y como una reacción historicista frente a las verdades de la historia sagrada, del otro.

Dentro de este proceso aparece la creciente importancia que han venido cobrando las ciencias experimentales o de la naturaleza, ${ }^{66}$ que implica la pérdida del halo mágico o sagrado que la naturaleza todavía poseía como la obra creadora de Dios. La historia natural, sustento de la física, cumplirá al respecto un papel primordial, entendida como la capacidad para contemplar a la naturaleza regulada por principios objetivos. Esta aptitud desarrollada inicialmente entre los naturalistas será luego trasladada al ámbito de la naturaleza humana, una naturaleza no innata, inmutable, sino perfectible. Esta transposición del ámbito natural al cultural abre la posibilidad de la formación de una historia sin más o "historia general", cuyo fundamento deja de ser externo al mismo devenir. La historia aparece entonces como un proceso regulado desde sí mismo y, por tanto, capaz de comprenderse a partir de sí misma.

Según Koselleck este fenómeno se dio en Alemania como resultado de un proceso de reflexión interna entre los letrados, así como de manera paralela pudo haberse presentado en la Francia de la llustración. En cambio para el caso iberoamericano parecería que el atisbo de un nuevo uso de la palabra historia no es producto de un proceso inmanente sino se presenta como un cheque en blanco relacionado con el país que se aspira ser; no es tanto el resultado de una experiencia, sino se proyecta como la apertura de nuevas posibilidades.

Podría parecer que en la descripción ofrecida por Koselleck se tiene una especie de relato teleológico: el caso alemán prefigura en el ámbito linguístico lo que sucedería después en el caso de los hechos políticos y sociales. La autocoronación de Napoleón podría simbolizar el establecimiento de ese punto cero o nacimiento de la nueva forma de historicidad, una forma que ya no requiere del pasado dinástico y canónico para existir, para obtener su legitimidad y aprobación. Pero ese inicio que señala un punto de ruptura radical con las formas del pasado conlleva a su vez una paradoja: ¿de qué manera se explica esa devoción y fascinación por el pasado que emergerá y se proyectará de muchas maneras en el futuro de ese pasado, nuestra modernidad? Así, la emergencia de un nuevo concepto de historia se realiza en el marco de una gran ambivalencia: autosuficiencia en relación con el presente, a la vez que deudora y necesitada de ese pasado para darle al presente el sustento del que carece. El problema es que se trata en principio de un pasado vaciado ya de su contenido moralizador tradicional.

En términos generales el caso español muestra bastantes coincidencias con el brasileño en cuanto a la evolución del término. En España no se encuentra la historia filosófica que caracterizaría el nuevo uso del término sino hasta las obras de autores como Donoso Cortés y Alberto Lista, es decir, entre 1830 y 1850 aproximadamente. Para el caso argentino propiamente no es sino con Sarmiento (1851), Mitre (1857) y Vicente Fidel López (1845) que se perfila el uso filosófico de la historia. Para México, la obra de José María Luis Mora, México y sus revoluciones (1836) es representativa de esta tendencia. Lo mismo que para Chile las reflexiones de Andrés Bello son ilustrativas de la presencia de la inflexión filosófica en la historia: "...sólo por los hechos de un pueblo individualizados, vivos, completos, podemos llegar a la filosofía de la historia de ese pueblo...". 
67

Las cursivas son mías. En Fabio Wasserman "Historia".
Parecería que la coexistencia de una línea clásica y otra moderna tiende a perderse en el momento en que se desarrolla un discurso filosófico de la historia; es decir, cuando la historia emerge en el horizonte como un problema. Es evidente que si los actores no experimentan la historia como ruptura, entonces se privilegiará la idea de una continuidad entre pasado y presente, condición para que el discurso histórico cumpla una función magisterial y pedagógica. Al mismo tiempo, en el contexto del proceso de independencia se muestra el surgimiento y predominancia de la historia contemporánea en la cual, sin embargo, se siguen asumiendo valores propios de la historia de antiguo régimen. Sólo implícitamente se reconoce que la historia cumple ante todo una función política, más que cognitiva.

Quizás Facundo. Civilización y barbarie (1845) de Domingo Sarmiento sea un caso paradigmático de la transformación ocurrida en la semántica de la historia. A todas luces Sarmiento es representativo de una noción tal como la descrita por Koselleck para Alemania. Al ser nombrado Director de Historia del Ateneo del Plata, Sarmiento declara en 1858: "(...) no hemos llegado a épocas definitivas en que las sociedades hayan tomado asiento, como el viajero que descansando ya bajo el techo hospitalario, vuelve retrospectivas miradas hacia el camino que ha andado. Nosotros escribimos la historia marchando".67 Esta declaración está describiendo de manera contundente la nueva experiencia de la temporalidad. La historia, orientada en principio diacrónicamente, ha terminado por sincronizarse con el espacio desde donde se escribe. El texto de Vicente Fidel López (1845) revela igualmente el desarrollo de una nueva sensibilidad respecto de la historia: "(...) la historia es la representación cientifica y literaria de todos los hechos que cambian el modo de ser de las naciones...." "(...) en esta ciencia está envuelta nada menos que la revelación de la naturaleza del hombre y de la sociedad (...) En la época en que vivimos tenemos todos una necesidad indispensable de estudios históricos. Todos somos ciudadanos capaces de obtener un puesto eminente en la dirección de los Estados, y nada hay más necesario, para dirigirlos bien, que conocer su naturaleza, para no violentarla ni permitirle extravíos peligrosos. Así, pues, el establecimiento del Gobierno Representativo ha hecho que la historia, que antes no era sino la ciencia de los príncipes, sea hoy la ciencia de los ciudadanos; [...]"

\section{Para concluir}

En este ensayo, finalmente, se ha buscado resaltar más las coincidencias que las diferencias mostradas en los nueve casos examinados. Se ha recurrido a la hipótesis desarrollada por Koselleck para iluminar el trayecto alemán hacia la historia moderna, y se ha encontrado que el caso iberoamericano no está muy lejano del mismo trazo. Si bien los factores, su combinación y su peso específico pueden diferir en cada uno de los casos estudiados. Por tanto lo que se ha tratado de dibujar aquí es una hipótesis general para seguir investigando y puntualizando las particularidades de cada uno de los procesos. En ese sentido todavía es prematuro intentar arrojar conclusiones definitivas.

En general se advierte que las coincidencias existentes se deben en buena medida a que se comparten referencias intelectuales y políticas afines. Para ello la imprenta y su inserción en algunos lugares al momento de las revoluciones ha venido a ocupar un papel central. Con ello se favorece la circulación de impresos y la información que permite que lo mismo pueda ser leído simultáneamente en diversos lugares. Habría que deta- 
Ilar aún más la recepción o formas de adaptación y traducción de obras extranjeras que se realizan en cada situación. Habría que ver también cómo las mismas denominaciones pueden adquirir valoraciones distintas, según circulen en lengua española o portuguesa.

Se ha podido apreciar que la formación del espacio de experiencia conocido como "moderno" en sentido estricto comienza a gestarse hacia 1808 y se manifiesta en la aparición de nuevos sintagmas relacionados con la palabra historia, tal como, "historia contemporánea" y "filosofía de la historia". Esto sucede en casi todos los casos hasta después de 1820, de manera más clara en el lapso de 1830-1850. Así, se puede postular que la transformación semántica de la historia en lberoamérica pasa a través de la redefinición de los proyectos imperiales español y portugués. Es con las independencias que se inicia un proceso de reelaboración conceptual de la herencia imperial en el seno del vocabulario político y social. En la medida en que el futuro esperado no se manifieste, la experiencia moderna de la historia irá tomando el perfil de una permanente transición. Como una forma de compensar la inestabilidad se irán tejiendo historias generales que den cuenta de los orígenes de la nación así como permitan avizorar el futuro esperado. Los relatos históricos adquirirán en ese sentido, un talante filosófico. Las diferentes formas que adquieran dependerán del lugar que se ocupe o se ha ocupado en el trayecto, si como parte de un imperio o en su defecto, como una ex/colonia.

Recebido para publicação em fevereiro de 2008 